\title{
Do Casamento à União Estável:
}

\author{
Aspectos Patrimoniais ${ }^{1}$
}

\section{Ester Lopes Peixoto \\ Mestranda em Direito Privado pela UFRGS}

"O progresso jurídico parece estar na cisão e continua ressistematização das relações jurídicas que se mostrem diversas."

Clóvis do Couto e Silvi ${ }^{2}$

Sumário: Introdução. I. Casamento: Regime de Bens. A) Disciplina do regime de bens no Código Civil. B) O tratamento dispensado ao regime de bens no Projeto do novo Código Civil. II. União Estável: Reflexos Patrimoniais. A) O regramento da Lei n.o 8.971/94. B) A disciplina da união estável na Lei n.o 9.278/96. C) O tratamento dispensado à união estável no Projeto do novo Código Civil. Conclusão. Bibliografia.

\footnotetext{
O presente ensaio foi apresentado na disciplina de Temas de Direito de Família, do Curso de PósGraduação Stricto Sensu da Faculdade de Direito da Universidade Federal do Rio Grande do Sul, sob a orientação da Prof. ${ }^{a}$ Dr. a Cláudia Lima Marques, no 2. Semestre de 2001.

2 Direito Patrimonial de Família no Projeto de Código Civil Brasileiro e no Direito Português. Revista dos Tribunais, v. 520, p. 15.
} 


\section{Introdução}

São incontáveis as transformações sócio-culturais que vêm sendo vivenciadas pela família nas últimas duas décadas ${ }^{3}$ as quais espelham uma sobreposição dos fatos às normas e despontam como sinais de transformação do porvir ${ }^{4}$.

\section{Com efeito, já não mais se mostrava suficiente ${ }^{5}$ a concepção de família estampada} pelo Código Civil ${ }^{6}$ fincada no "liame estabelecido entre legitimidade e casamento, estatuindo um 'desvalor' às relações não-matrimonializadas" . Assim, as manifestações da doutrina e jurisprudência ${ }^{8}$ que palmilhando por trilhas incertas buscavam através de construções oferecer uma justa interpretação do Direito.

\footnotetext{
${ }^{3}$ Neste sentido, as observaçōes de Sérgio Gischkow PEREIRA: "São ambos os pais forçados a trabalhar fora do lar, da mesma forma que os filhos, visando a aumentar a renda familiar, em função das crises econômico-financeiras do capitalismo e da absoluta miséria que assola as grandes massas populacionais; é a pobreza produzindo a tensão no ambiente familiar, a violência, o alcoolismo, a saída para as ruas dos menores, desde a mais tenra idade, a vida sem perspectivas de realização, o esmagamento de todas as potencialidades humanas; é a necessidade de crescimento do grupo familiar, quando abalado pela carência material, como forma de reforço dos ingressos monetários e de diversas outras maneiras de sustentação; é a fragmentação da solidez moral vitoriana, em um mundo no qual as estruturas de referência desabam, sob uma crítica científica e filosófica implacáveis no desmascaramento dos mitos, das superstiçōes, das ilusōes e das certezas, buscando a construção de um mundo novo, alicerçado no conhecimento nāo deturpado das qualidades e limitações do homem; é a velocidade fantástica das mudanças em todos os setores da vida, terminando com a placidez das convicções não erigidas sobre o aprofundamento analítico; é, no campo da ciência, em especial, o desvelamento psicanalítico das opressões e pressões familiares; é a tendência de todos os seres humanos a pelo caminho da liberdade, atingirem o bem-estar, a igualdade, o respeito incondicional à dignidade, a realização de seus potenciais (...)". "Tendências modernas no direito de família". Revista Ajuris, v. 42. p. 83-4.

${ }^{4}$ Acentua Luiz Edson FACHIN que: "A releitura de estatutos fundamentais do Direito Privado é útil e necessária para compreender a crise e a superação do sistema clássico que se projetou para o contrato, a família e o patrimônio." "Direito Civil Contemporâneo". Revista Consulex, n.ำ18, Jun/98, p. 32-4.

${ }^{5}$ Neste sentido, Cláudia Lima MARQUES, Maria Cláudia CACHAPUZ e Ana Paula da Silva VITÓRIA. comentando sobre os desafios dos "chamados tempos pós-modernos" apontam para "insuficiência do modelo familiar tradicional, modelo patriarcal do direito civil moderno, o que leva a evolução dos conceitos, à maior maleabilidade na jurisprudência, nos valores e visões por ela consolidados, seja ideológica, seja discursivamente." "Igualdade entre filhos no direito brasileiro atual - direito pós-modemo?" Revista dos Tribunais, v. 764, p. 13.

${ }^{6}$ Silvio RODRIGUES em precioso estudo, ressalta a importância do casamento e da família tradicional no Código Civil: "O livro de Direito de Família do C.C. dedica 149 de seus 304 artigos ao casamento (...)" Em outra passagem refere: "(...) o casamento era o elemento estrutural no Direito de Família no Brasil, na forma por que o disciplinou o Código de 1916." Prossegue o autor: "A família de que cuida o legislador de 1916 é a tradicional, inspirada no privilégio da varonia (...)" "Breve histórico sobre o direito de família nos últimos 100 anos". In Revista da Faculdade de Direito da Universidade de São Paulo, v. 88, 1993, p. 241.

${ }^{7}$ Luiz Edson FACHIN. "Contribuição crítica à teoria das entidades familiares extramatrimoniais". In Repertório de Jurisprudência e Doutrina sobre Direito de Família. Aspectos constitucionais, civis e processuais, v. 3. (Coord.) Teresa Arruda ALVIM. São Paulo: Revista dos Tribunais. 1996, p. 94-113.

${ }^{8}$ A propósito, menciona Luiz Edson FACHIN. "(...) O Supremo Tribunal Federal, da década de 50 até o início da apreciação dessas matérias pelo Superior Tribunal de Justiça, construiu, sem embargo de algumas sístoles e diástoles, um conjunto de preceitos jurisprudenciais que promoveu uma atualizaçāo e uma adaptação e, em casos expressivos, levou em conta princípios outros que não aqueles que veiculavam as regras positivadas do Código Civil. Daí porque, no transcurso do Código, na Constituição de 1988, há nesse País um papel decisivo da jurisprudência, de algumas leis infraconstitucionais (...) e também da doutrina. "Projeto do Código Civil". Revista do Centro de Estudos Judiciários - CEJ, n. 9, Dez/99, p. 18. A par disso, o próprio enunciado da Súmula 380 do STF exemplifica o que ora se está a afirmar.
} 
Tal contexto 9 , impulsionou as mudanças implantadas com o advento da Constituição Federal de 1988, a qual assimilando a realidade fática ${ }^{10}$ existente concebeu um novo paradigma de família ${ }^{11}$, inspirado numa "dimensão sociológica e plural das entidades familiares". ${ }^{12 \mathrm{e} 13}$

Como acentua Sérgio Gischkow Pereira: "o direito de família evolui para um estágio em que as relaçóes familiares se impregnem de autenticidade, sinceridade, amor, compreensão, diálogo, paridade, realidade." 14

Privilegia-se, assim, o aspecto interno - a afetividade ${ }^{15}$ - das relaçóes familiares ${ }^{16}$ que se alicerçam em valores autênticos. Neste sentido, destaca ERIK JAYME ${ }^{17} \mathrm{o}$ "retorno dos sentimentos" como um dos valores da pós-modernidade ${ }^{18}$.

\footnotetext{
${ }^{9}$ Como percebe Orlando GOMES estas mudanças acabaram por repercutir na própria "ratio do matrimônio" desmestificando o modelo de familia desenhado pelo Código Civil. Direito de Família, 9. ${ }^{a}$ ed. Rio de Janeiro: Forense. 1996. p. 16.

10 Veja-se, a propósito retrospecto histórico sobre as origens da família e do concubinato feito por Antônio Carlos Mathias COLTRO. “A União Estável: um conceito?" In Repertório de Jurisprudência e Doutrina sobre Direito de Família. Aspectos constitucionais, civis e processuais, v. 3, (Coord.) Teresa Arruda ALVIM. São Paulo: Revista dos Tribunais. 1996, p. 19-27.

1 Neste sentido, acentua Gustavo José Mendes TEPEDINO que: "A Constituição desloca a prioridade, antes atribuída ao casamento, para a dignidade de cada um dos familiares. A unidade institucional, formada pelo casamento (cuja importância sobrepunha-se às pessoas), dá lugar à unidade da familia, agora considerada em função da plena realização de seus membros." "Qual a Lei para a Nova Familia?" In Revista Jurídica, Dez/1999, n.ำ 7, p. 24.

12 Luiz Edson FACHIN. "Projeto do Código Civil". Revista do Centro de Estudos Judiciários - CEJ,

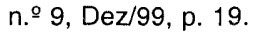

${ }^{13}$ O mesmo autor em outro trabalho acentua: "A família não é mais uma única definição. (...) Ela se torna plural." A seguir acrescenta: "Proclama-se a concepção eudemonista da família: não é mais o indivíduo que existe para a familia e para o casamento, mas a família e o casamento existem para 0 seu desenvolvimento pessoal, em busca de sua aspiração à felicidade." Luiz Edson FACHIN. "A desinstitucionalização do modelo familiar: possibilidades e paradoxos sob o neoliberalismo". Revista do Direito, Santa Cruz do Sul, n. ${ }^{2} 12$, p. 13-8, jul-dez/99, p. 16-7.

${ }^{14}$ Ob. cit. p. 52.

15 Como ensina Eduardo CAMBI: "A affectio deve ser a única ratio das uniões matrimonializadas ou não, sendo papel da família a promoção do bem-estar de seus membros, com respeito à esfera individual de cada um." "Premissas teóricas das uniões extramatrimoniais no contexto da tendência da personificação do Direito de Família". In Repertório de Jurisprudência e Doutrina sobre Direito de Familia. Aspectos constitucionais, civis e processuais, v. 4. (Coord.) Teresa Arruda Alvim WAMBIER e Eduardo Oliveira LEITE. São Paulo: Revista dos Tribunais, 1999. p. 133.

16 É o chamado "fenômeno da repersonalização" ou "personificação", veja-se sobre o assunto: Paulo Luiz Netto LÔBO. "A repersonalização das relações de família". In O Direito de Família e a Constituição de 1988. (Coord.) BITTAR, Carlos Alberto. São Paulo: Saraiva, 1989. p. 53-81; e Eduardo $\mathrm{CAMBI}$. "Premissas teóricas das uniões extramatrimoniais no contexto da tendência da personificação do Direito de Familia". In Repertório de Jurisprudência e Doutrina sobre Direito de Família. Aspectos constitucionais, civis e processuais, v. 4. (Coord.) WAMBIER, Teresa Arruda Alvim e LEITE, Eduardo Oliveira. São Paulo: Revista dos Tribunais, 1999. p. 125-87.

${ }^{17}$ Erik JAYME. "Visões para uma teoria pós-moderna do direito comparado". Revista dos Tribunais, v. 759. p. 29.

${ }^{18}$ Sobre o tema veja-se Jean-François LYOTARD. A condição pós-moderna. Trad. Ricardo Corrêa Barbosa. 5. ed., Rio de Janeiro: Ed. José Olympio, 1998.
} 
Nesta esteira, LuIz EDSON FACHIN lembra que "uma das maiores conquistas do final deste século foi precisamente o respeito ao que somos, à diferença, porque da convivência entre os diferentes, da harmonia na adversidade é que pode emergir a perspectiva de uma relação familiar justa, afetiva e, por via de conseqüência, de uma sociedade justa que também valoriza as relações afetivas." ${ }^{19}$

A Constituição Federal de $1988^{20}$ permitiu, então, uma nova leitura do direito de família ao reconhecer que paralelamente à família legítima, constituída pelo casamento, regulada pelo Código Civil, está a união estável ${ }^{21}$ - como expressão da realidade humana - a qual elevou à categoria de entidade familiar. ${ }^{22 \mathrm{e}} 23$

O § 3. do art. 226 da Constituição Federal ${ }^{24}$, todavia, não se preocupou em conceituar o novo instituto, porém impôs como exigência para configuração da união

19 Luiz Edson FACHIN. "Projeto do Código Civil". Revista do Centro de Estudos Judiciários - CEJ, n. 9 , Dez/99, p. 19.

20 Veja-se a respeito, Antônio Carlos Mathias COLTRO. "A Constituição Federal e a União Estável entre Homem e Mulher". In Repertório de Jurisprudência e Doutrina sobre Direito de Família. Aspectos constitucionais, civis e processuais, v. 1, (Coord.) Teresa Arruda ALVIM. São Paulo: Revista dos Tribunais, 1993 , p. $42-56$.

${ }^{21}$ Eduardo Oliveira LEITE critica a expressão ao referir: "O concubinato mereceu consagração constitucional, sob a denominação equivocada de 'união estável' (como se o casamento 'legítimo' não fosse também uma 'uniāo estável'). Melhor seria que o constituinte tivesse se referido à 'união livre' (sem impedimentos matrimoniais, portanto)." "O concubinato frente à nova Constituição hesitações e incertezas". In Repertório de Jurisprudência e Doutrina sobre Direito de Família. Aspectos constitucionais, civis e processuais, v. 1, (Coord.) Teresa Arruda ALVIM. São Paulo: Revista dos Tribunais, 1993, p. 97.

${ }_{22}$ Neste sentido, assinala Eroulths Cortiano JUNIOR que: "Essa nova tábua valorativa faz com que a ordem jurídico-constitucional, dando azo às modificações das estruturas sociais a que respeita o direito de família, reconheça as entidades familiares como centro da tutela jurídica. "O Direito de Família no Projeto do Código Civil". In Repertório de Jurisprudência e Doutrina sobre Direito de Família. Aspectos constitucionais, civis e processuais, v. 4. (Coord.) Teresa Arruda Alvim WAMBIER e Eduardo Oliveira LEITE. São Paulo: Revista dos Tribunais, 1999. p. 232.

${ }^{23}$ Atento a essas transformações o Tribunal de Justiça do Rio Grande do Sul, por suas Colendas Câmaras, passou a enquadrar o concubinato ou, melhor, a união estável na regramento familiar excluindo, assim, 0 tratamento que vinculava estas relações às sociedades de fato. Neste sentido: AC 590088969, 8. ${ }^{a}$ Câmara Cível, Rel. Clarindo Favretto, j. em 02.05.91; AC 591056239, 8." Câmara Civel, Rel. Clarindo Favretto, j. em 03.10.31; AC 594086415, 8. a Câmara Cível, Rel. Leo Afonso Einloft Pereira, j. em 29.09.94. Anoto que, aqui, o recuo no tempo quanto à pesquisa jurisprudencial é intencional.

${ }^{24}$ A redação do dispositivo é a seguinte: "Art. 226. A familia, base da sociedade, tem especial proteção do Estado.

§ 3. ${ }^{\circ}$ Para efeito da proteção do Estado, é reconhecida a união estável entre o homem e a mulher como entidade familiar, devendo a lei facilitar sua conversäo em casamento. 
estável a diferença de $\operatorname{sexos}^{25}$ Passados mais de 10 anos da edição da Carta Constitucional poder-se-ia, até mesmo, cogitar da constitucionalidade deste requisito, uma vez que são notórias uniôes homossexuais na sociedade atual. Tal fato, aliás, tem sido objeto de investigações e estudos. Assim, Maria Berenice DIAS.

“União Homossexual - Aspectos sociais e jurídicos". Revista Brasileira de Direito de Família, n.o 4, p. 5-14; Luiz Edson FACHIN.

"Aspectos Jurídicos da União de Pessoas do Mesmo Sexo". Revista dos Tribunais, v. 732, p. 47-54.

Entretanto, a jurisprudência do nosso Tribunal de Justiça, com pequenas oscilações, ainda tende a considerar como indispensável tal requisito é o que se infere das ementas que se seguem:

"Agravo de instrumento. O relacionamento homossexual não está amparado pela Lei 8.971, de 21 de dezembro de 1994, e Lei 9.278, de 10 de maio de 1996, o que impede a cncessão de alimentos para uma das partes, pois o envolvimento amoroso de

\footnotetext{
${ }^{25}$ Passados mais de 10 anos da edição da Carta Constitucional poder-se-ia, até mesmo, cogitar da constitucionalidade deste requisito, uma vez que são notórias uniões homossexuais na sociedade atual. Tal fato, aliás, tem sido objeto de investigações e estudos. Assim, Maria Berenice DIAS. "Uniāo Homossexual - Aspectos sociais e jurídicos". Revista Brasileira de Direito de Família, n. 4, p. 5-14; Luiz Edson FACHIN. "Aspectos Jurídicos da Uniāo de Pessoas do Mesmo Sexo". Revista dos Tribunais, v. 732, p. 47-54. Entretarito, a jurisprudência do nosso Tribunal de Justiça, com pequenas oscilações, ainda tende a considerar como indispensável tal requisito é o que se infere das ementas que se seguem:

"Agravo de instrumento. O relacionamento homossexual nāo está amparado pela Lei 8.971, de 21 de dezembro de 1994, e Lei 9.278, de 10 de maio de 1996, o que impede a cncessão de alimentos para uma das partes, pois o envolvimento amoroso de duas mulheres não se constitui união estável, e semelhante convivência traduz uma sociedade de fato. Voto vencido." (Agravo de Instrumento $\mathrm{n}$. 7000535542, 8. ․ Câmara Civel, Rel. Antônio Carlos Stangler Pereira, j. em 13.04.2000)

"Apelação. Relacionamento homossexual. Inexistência de união estável. Impossibilidade do sobrevivente se beneficiar da herança do falecido nos termos do artigo $2 .{ }^{\circ}$, inciso III, da Lei $8.971 /$ 94. O relacionamento homossexual de dois homens, não se constitui em união estável para os

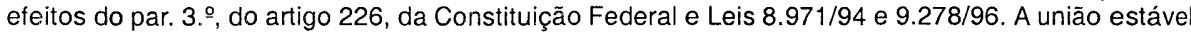
para ser reconhecida como entidade familiar, exige a convivência duradoura, pública e contínua de um homem e uma mulher, estabelecida com objetivo de constituição de família, inclusive com a possibilidade de sua conversão em casamento. As outras espécies de uniões informais, que não se encaixem na noção de companheirismo, inclusive entre pessoas do mesmo sexo, estão abrangidas pela Súmula 380, do Supremo Tribunal Federal." (Apelação Cível n. ${ }^{\circledR} 599348562,8 .{ }^{a}$ Câmara Cível, Rel. Antônio Carlos Stangler Pereira, j. em 11.10.2001)

"União homossexual. Reconhecimento. Partilha do patrimônio. Meação paradigma. Não se permite mais o farisaísmo de desconhecer a existência de uniōes entre pessoas do mesmo sexo e a produção de efeitos jurídicos derivados dessas relaçōes homoafetivas. Embora permeadas de preconceitos, são realidades que o judiciário não pode ignorar, mesmo em sua natural atividade retardatária. Nelas remanescem conseqüencias semelhantes as que vigoram nas relações de afeto, buscandose sempre a aplicação da analogia e dos princípios gerais do direito, relevando sempre os princípios constitucionais da dignidade humana e da igualdade. Desta forma, o patrimônio havido na constância do relacionamento deve ser partilhado como na união estável, paradigma supletivo onde se debruça a melhor hermenêutica. Apelação provida, em parte, por maioria, para assegurar a divisão do acervo entre os parceiros." (Apelação Cível n.70001388982, 7. a Câmara Civel, Rel. José Carlos Teixeira Giorgis, j. em 14.03.2001)
} 
duas mulheres não se constitui união estável, e semelhante convivência traduz uma sociedade de fato. Voto vencido." (Agravo de Instrumento n. 7000535542, 8. a Câmara Cível, Rel. Antônio Carlos Stangler Pereira, j. em 13.04.2000).

Embora, o delineamento final da união estável fosse traçado pela legislação infraconstitucional os parâmetros apontados pela nova Carta serviram de amparo à jurisprudência, possibilitando a aplicação do regramento ali consubstanciado.

Neste contexto, surgiu a Lei n.ㅇ 8.971/94 a qual seguiu-se a Lei n.. 9.278/96, ambas disciplinadoras de aspectos relativos à união estável e seus reflexos.

É com base nestes novos contornos impostos às relações familiares que pretendemos analisar os efeitos decorrentes do regime de bens escolhido no casamento (I) e, bem assim, os aspectos patrimoniais surgidos em face da convivência na união estável (II).

\section{CASAMENTO: REGIME DE BENS}

A eleição do regime de bens e as conseqüências que tal escolha irá representar na vida dos nubentes é, sem dúvida, tema de altíssima importância. Isto porque, a par de ser imutável ${ }^{26} \mathrm{e}^{27}$ o regime de bens irá disciplinar o aspecto patrimonial ${ }^{28}$ que envolve a "comunhão" de interesses no matrimônio.

Essa peculiaridade autoriza, inclusive, que em determinadas circunstâncias o próprio legislador se sobreponha à vontade dos nubentes, determinando o regime a ser adotado é o que ocorre, por exemplo, quando a lei impóe como obrigatório o regime da separação de bens. ${ }^{29}$

A análise dos diferentes regimes de bens que se procederá a seguir, leva em consideração dois aspectos: o regramento constante no Código Civil (A) e o tratamento dispensado ao regime de bens no Projeto do novo Código Civil (B).

A) Disciplina do regime de bens no Código Civil

\footnotetext{
${ }^{26}$ Há quem, como Orlando GOMES, questione a validade de tal imposição sugerindo a possibilidade de mutabilidade do regime matrimonial, observadas determinadas exigências, por forma a evitar os abusos e resguardar os interesses de terceiros. Ob. cit. p. 166.

27 Exceção a esta regra vem contemplada no $\S 5 .^{\circ}$ do art. $7 .^{\circ}$ da LICC que permite ao estrangeiro casado que se naturalizar brasileiro, adotar o regime da comunhão parcial de bens alterando, assim, o anterior regime.

${ }^{28} \mathrm{Na}$ lição de Orlando GOMES, "Regime matrimonial é o conjunto de regras aplicáveis à sociedade conjugal considerada sob o aspecto dos seus interesses patrimoniais. Em síntese, o estatuto patrimonial dos cônjuges." Ob. cit., p. 165.

${ }_{29}$ Esta previsāo vem estampada no parágrafo único do art. 258 , C. Civil.
} 
No sistema atual, os regimes de bens classificam-se em dois tipos ${ }^{30}:$ regimes comunitários e regimes não-comunitários. Os primeiros, são representados pela comunhão universal e pela comunhão parcial, nas suas diferentes modalidades, ao passo que, nos segundos incluem-se a separação absoluta e o regime dotal.

Antes de passarmos ao exame das diversas espécies, convém lembrar os princípios que orientam a disciplina do regime de bens, são eles: a) variedade dos regimes; b) liberdade dos pactos antenupciais; e c) imutabilidadedo regime adotado. ${ }^{31}$

Cumpre, também, observar que além dos regimes específicos, admite o legislador que as partes convencionem regime diverso, mediante estipulação em pacto antenupcial $^{32}$. Assim, podem os nubentes em náo desejando se submeter ao regime legal adotar, mediante convenção solene, qualquer outro dos regimes previstos em lei ou, ainda, estipular regime misto oriundo da combinação daqueles já existentes, observadas as restriçōes legais. ${ }^{33}$ e 34

A validade do pacto sujeita-se a observância de dois requisitos: pública forma e efetiva celebração do casamento..$^{35}$

Feitas estas observações, passamos a examinar os regimes matrimoniais em espécie $^{36}$. O Código Civil cuida da matéria na Parte Especial, Livro I - Do Direito de Família, Título III - Do Regime dos Bens entre os Cônjuges, artigos 256 a 314.

\section{a) Regime da Comunhão Parcial ou Limitada}

\footnotetext{
30 A classificação foi recolhida em Orlando GOMES, Ob. cit., p. 169.

31 Assim, Orlando GOMES, Ob. cit., p. 165.

32 Orlando GOMES o define como sendo a: "convenção solene na qual os nubentes declaram adotar um dos regimes definidos na lei ou estipulam regime misto." Ob. cit., p. 169.

${ }^{33}$ Inobstante o texto original apresentado, permitiu-se, posteriormente, um avanço quanto à pesquisa de jurisprudência, visando a realçar as tendências aqui expostas.

${ }^{34}$ A propósito da imutabilidade do regime de bens e da necessidade de observância das formalidades relativas ao pacto antenupcial, já decidiu o Tribunal de Justiça do Rio Grande do Sul ao apreciar a Apelação Cível n.ำ 70001865849, 7. a Câmara Cível, Rel. Sérgio Fernando Vasconcellos Chaves, j. em 21.02.2001, assim ementada:

"Pedido de alvará judicial. Autorização para lavrar escritura pública de pacto antenupcial com efeito retroativo. Impossibilidade jurídica. Nāo tendo havido pacto antenupcial, o regime de bens do casamento era o da comunhão parcial (art. 258, CCB) e esse regime é imutável e irrevogável (art. $231, \mathrm{CCB}$ ), não podendo ser alterado, agora, pela pretendida escritura pública. É nula a convenção acerca do regime de bens, quando não constar de escritura pública (art. 356, inc. I, CCB). Existe mero erro material na certidão de casamento já que, onde consta regime comunhão universal, deveria constar regime da comunhão parcial. Recurso desprovido." (Grifamos)

${ }_{35}$ Veja-se, entre outros, Caio Mário da Silva PEREIRA. Instituições de Direito Civil. Rio de Janeiro: Forense, vol. V, 9. ed., 1994, p. 117.

${ }^{36}$ As observações que seguem serão traçadas de modo genérico e visam a realçar os principais aspectos do regime examinado, situando o leitor no contexto e, bem assim, destacando os pontos relevantes para o presente estudo.
} 
Nas palavras de Caio Mário da Silva Pereira: "O direito brasileiro disciplina como regime de comunhão parcial o que alguns civilistas antigos designavam como 'separação' (LAFAYETTE, MElo Freire, CoelHo DA ROCHA) e mais adequadamente TEIXEIRA DE FreITAS denominava 'regime misto' (Consolidação, art. 88, nota 16), e que se pode simplesmente chamar de 'comunhão de aqüestos'."37

O regime da comunhão parcial ganhou importância no nosso sistema a partir da edição da Lei do Divórcio (Lei n. $96.515 / 77$, art. 50) que o consagrou como regime legal ${ }^{38}$ superando a hegemonia do regime da comunhão universal que até então ocupava esse lugar.

Assim, na falta de estipulação em contrário, prevalece o regime de comunhão parcial ou limitada, segundo o qual comunicam-se os bens adquiridos, a título oneroso, na constância do casamento (art. 271, C. Civil).

A restrição ${ }^{39}$ a que os bens adquiridos a título gratuito, ainda que na constância do matrimônio, incluam-se na comunhão é o que a torna limitada apontando, também, para distinção em relação ao regime de comunhão universal..$^{40}$

O regime passa a vigorar a partir do momento em que o casamento é contraído validamente. Neste sentido, ORLANDo Gomes reproduzindo lição de Planiol e RIPERT acentua que: "O regime da comunhão parcial é tido como o que melhor realiza a idéia de colaboração ínsita aos regimes comunitários, pois a estabelece a partir do momento em que nasce a sociedade conjugal." ${ }^{41}$

O regime da comunhão parcial caracteriza-se pela existência conjunta de três patrimônios distintos, a saber: a) patrimônio comum; b) patrimônio pessoal do marido; e c) patrimônio pessoal da mulher. ${ }^{42}$

Em razão da coexistência desses três patrimônios distintos, ocorrendo a dissolução da sociedade conjugal pela morte de um dos cônjuges, os bens pessoais do cônjuge

${ }^{37}$ Ob. cit., p. 125.

38 João Andrades CARVALHO critica a expressão dizendo que "essa denominação pode levar à lógica depreensão de que os outros são regimes ilegais." Regime de bens. Rio de Janeiro: Aide, 1996. p. 21. Contudo, entendemos mais oportuna a observação de Silvio RODRIGUES segundo a qual: "O regime legai se opõe ao convencional, porque, enquanto o primeiro decorre da vontade dos nubentes, o segundo emerge da lei." Direito Civil. vol. VI, 16. a ed. atual., São Paulo: Saraiva, 1989. p. 172.

${ }_{39}$ Veja-se o disposto no art. 269, C. Civil e, ainda, o art. 170 do mesmo diploma legal.

40 Orlando GOMES. Ob. cit., p. 175.

41 Ob. cit., p. 177.

42 A classificação é recolhida em Orlando GOMES. Ob. cit. p. 176. 
falecido serão entregues aos herdeiros. Ao passo que, na dissolução por separação judicial ou divórcio ${ }^{43} \mathrm{a}$ partilha incidirá apenas sobre os bens comuns.

\section{Por força do art. $226, \S 5$. , $\mathrm{CF}^{4444} \mathrm{O}$ dispositivo tem a seguinte redação:}

os bens comuns são administrados por ambos os cônjuges ${ }^{45}$. A regra é que cada cônjuge administra o seu patrimônio pessoal. Na hipótese, de vir o marido administrar os bens pessoais da mulher age como seu representante.

Também não tem mais lugar, ante a isonomia determinada pelo mencionado dispositivo constitucional, a permanência da categoria de bens reservados ${ }^{46} \mathrm{da} \mathrm{mulher.}^{47}$

Com relação às dívidas tem-se que os cônjuges respondem, conjuntamente, pelas obrigações assumidas após o casamento ${ }^{48}$, bem como, por aquelas contraídas por apenas um dos cônjuges com o consentimento do outro e, ainda, por aquelas que se destinam a atender os compromissos da vida famíliar. ${ }^{49}$

Por conseguinte, cada cônjuge responde, individualmente, pelas obrigações anteriores ao casamento, bem como, por aquelas decorrentes de atos ilícitos ${ }^{50}$. Também,

43 Ilustrativa, a propósito, é a manifestação do Tribunal de Justiça do Rio Grande do Sul ao apreciar a Apelação Cível n.o 598525079, 8. a Câmara Cível, Rel. Alzir Felippe Schmitz, j. em 13.04.2000, assim ementada: "Apelaçāo civel. Conversāo de separaçāo judicial em divórcio. Partilha de bens integrantes do patrimônio do casal. Julgamento ultra petita. Não ocorrência. Ante o regime de bens adotado (comunhão parcial) devem ser partilhados aqueles atribuídos na constância do casamento, se não demonstrado nos autos que obtidos com valores de que já era possuidor um dos cônjuges, quando do matrimônio. Assim como os bens, também as dívidas ou despesas, comprovadamente efetuadas em benefício do casal, devem ser partilhadas entre os divorciandos. Sendo amplo o pedido contido na inicial permitida a decisão nos termos em que posta a sentença. Apelos nāo-providos." (Grifos no original)

44 O dispositivo tem a seguinte redação: "Art. 226. A família, base da sociedade, tem especial proteção do Estado.(...)“§ 5.ำ Os direitos e deveres referentes à sociedade conjugal são exercidos igualmente pelo homem e pela mulher."

45 Confira-se Silvio RODRIGUES. Ob. cit., p. 205.

46 Neste sentido, a jurisprudência tem posiçōes bem definidas (1) aplicando o instituto dos bens reservados nas situações anteriores ao advento da Carta Constitucional: AC 585044514, Rel. Sérgio Pilla da Silva, 5. a Câmara Cível, TJRS; j. em 04.02.1986; AC 597112648, Rel. Eliseu Gomes Torres, 7." Câmara Cível, TJRS, j. em 20.08.1997; AC 597082775, Rel. Ivan Leomar Bruxel, 8. ํa Câmara Cível, TJRS, j. em 23.10.1997; AC 599404100, Rel. Breno Moreira Mussi, 8. a Câmara Cível, TJRS, j. em 14.10.99; e (2) reconhecendo que a igualdade imposta pelo texto constitucional impede se reconheça bens reservados em favor da mulher: AC 194158408, Rel. Juracy Vilela de Souza, 1. a Câmara Cível, TARGS, j. em 20.09.1994; El 594171696, Rel. Eliseu Gomes Torres, 4.ํㅡ Grupo Cível, TJRS, j. em 09.06.1995; AC 597014562, Rel. Sérgio Fernando de Vasconcellos Chaves, 7. ${ }^{\circledR}$ Câmara Cível, TJRS, j. em 07.05.1997. Aqui, também, o recuo no tempo quanto à pesquisa é intencional.

47 Veja-se, a propósito Paulo Luiz da Costa LÔBO. "Igualdade conjugal - direitos e deveres". Revista da Esmape, v. 2, n. 9 6, out/dez - 1997, p. 361-80.

48 Art. 270,1 , C. Civil, a contrario sensu.

49 Orlando GOMES. Ob. cit., p. 181.

50 Art. 270, II, C. Civil. 
responde exclusivamente o cônjuge pelas dívidas relacionadas a bens próprios e por aquelas contraídas sem a autorização do outro cônjuge que excedem os limites permitidos.

Demais dívidas contraídas por um dos cônjuges, na qualidade de administrador dos bens do casal, alcançam além dos bens comuns os particulares de cada cônjuge de acordo com o proveito que tenha havido.

Quanto à possibilidade de intervenção judicial ${ }^{51}$ entendemos que é admissível, apenas, quando um dos cônjuges se opuser, injustificadamente, à prática de ato que necessita de sua concorrência. Podendo, em caso tal, o juiz suprir a outorga.

b) Regime da Comunhão Universal

O regime da comunhão universal ${ }^{52}$, herança do direito luso, serviu por muitos $\operatorname{anos}^{53}$ como regime legal. A opção explicava-se à época, considerados os valores que preponderavam na sociedade oitocentista. ${ }^{54 \mathrm{e} 55}$

Este regime caracteriza-se pela comunhão dos bens que cada cônjuge possuía ao casar e, bem assim, pela comunhão daqueles adquiridos após a celebração do casamento. Na sociedade conjugal, vigora o chamado estado de indivisão segundo o qual cada um dos cônjuges dispóe de metade ideal do patrimônio comum..$^{56}$

Para SILvio RodRIGUES ${ }^{57}$, o regime da comunhão universal assemelha-se a um condomínio uma vez que os patrimônios pessoais fundem-se em um único, passando ambos os cônjuges à condição de condômino em relação ao novo patrimônio.

51 Orlando GOMES, destaca além desta outra hipótese: "quando o marido não pode prestá-lo, sem que, no entanto, tenha perdido a condição de cabeça do casaf'. Ob. cit., p. 187. Afastamos esta situação ante o preceito estatuído no $\S 5.9$, art. 226, CF.

52 Veja-se o disposto nos arts. 262 a 268, C. Civil.

53 Desde a promulgação do Código Civil de 1916 até a edição da Lei do Divórcio, em 1977 que, como visto, no ponto substitui-o pelo regime da comunhão parcial.

54 A este propósito, observa PONTES DE MIRANDA que o nosso Código Civil se constitui no "antepenúltimo Código do século passado". Fontes e evolução do direito civil brasileiro, p. 87.

55 Neste sentido, a observação de Silvio RODRIGUES reportando-se ao quanto se encontrava expresso nas Ordenações do Reino que, no particular, assim dispunham: "Todos os casamentos feitos em nossos reinos e senhorios se entendem feitos por carta de ametade: salvo quando entre as partes outra coisa fôr acordada e contratada, porque entāo se guardará o que entre elas fôr contratado." Ob. cit., p. 173.

56 Assim, Orlando GOMES. Ob. cit., p. 188.

57 Ob. cit., p. 190 
Diversa é a posição de ORLANDo GOMEs, segundo o qual os cônjuges não são proprietários dos bens que integram o patrimônio comum, modo individualizado, mas, sim, do conjunto que compõe esse patrimônio. Daí afirmar: "Não se trata de condomínio propriamente dito, porquanto nenhum dos cônjuges pode dispor de sua parte nem exigir a divisão dos bens comuns. Tais bens são objeto de propriedade coletiva, a propriedade de mão comum dos alemães, cujos titulares são ambos os cônjuges." 58

Neste sentido, também, a opinião de Clóvis do Couto e Sinva a qual nos filiamos, ao explicitar: "É que o regime de comunhão difere essencialmente do condomínio. Neste último há, no caso de pluralidade de proprietários sobre um mesmo bem, a divisão de quotas ideais. Essas quotas constituem, à sua vez, propriedade particular de cada um dos condôminos. Sucede, porém, que no regime de comunhão o mesmo fenômeno não se verifica, já que não se divide idealmente em quotas, suscetíveis de propriedade particular. Não havendo esse seccionamento do direito de propriedade particular, a legitimação de seus titulares é conjunta ou em mão comum." 59

O regime da comunhão universal comporta, entretanto, algumas restrições que consistem na exclusão de determinados bens da comunhão, tais hipóteses vem estampadas no art. 263, C. Civil. Com efeito, não obstante a denominação atribuída ao regime percebe-se que, em verdade, trata-se de comunhão não integral.

Os princípios que orientam a comunhão universal são os seguintes: a) os bens que ingressam na sociedade conjugal ficam, de regra, subordinados à comunhão; b) os bens adquiridos individualmente por um dos cônjuges passam a integrar o acervo comum a partir da aquisição; c) cada um dos cônjuges possui metade ideal dos bens que compōem a sociedade conjugal, inobstante um deles nada contribua ou nada venha adquirir na constância do matrimônio ${ }^{60}$.

A exemplo do que ocorre no regime da comunhão parcial, aqui, também, compete a ambos os cônjuges a administração dos bens comuns em razão do que preceitua o art. $226, \S 5 . \stackrel{\circ}{\mathrm{o}} \mathrm{CF}$.

No que se refere às dívidas a regra é a comunicabilidade. Neste sentido, alcançam até mesmo àquelas contraídas antes do casamento, desde tenham revertido em proveito comum dos cônjuges ou tenham sido contraídas para atender despesas com seus preparativos. $^{61}$

58 Ob. cit., p. 189.

59 Clóvis do COUTO E SILVA. "Direito Patrimonial de Família". Revista da Faculdade de Direito da UFRGS, v. 1, p. 49.

60 A classificação é feita por Orlando GOMES. Ob. cit., p. 188.

61 Assim, Orlando GOMES. Ob. cit., p. 190. 
Não se comunicam ${ }^{62}$, contudo, aquelas decorrentes de ato ilícito, as que tenham origem em fiança prestada sem o consentimento do outro cônjuge e, ainda, as que configurem promessa ou constituição de dote feita, exclusivamente, por um dos cônjuges a filho comum, ou, ainda, em favor de filho seu.

No atual sistema, os bens comuns respondem pelas obrigações assumidas, apenas, por um dos cônjuges até o limite de sua meação.

Extingue-se o regime com a dissolução da sociedade conjugal: a) pela morte de um dos cônjuges; b) pela sentença anulatória do casamento; c) pela separação judicial e d) pelo divórcio. . $^{\text {e } 64}$

Inobstante o término da comunhão, os bens permanecem indivisos até a realização da partilha.

c) Regime da Separação

Na lição de ORLANDO GOMEs, "o regime da separação caracteriza-se pela incomunicabilidade dos bens presentes e futuros dos cônjuges" ${ }^{65}$. Os patrimônios dos cônjuges não se comunicam, permanecendo cada qual com a propriedade, administração e disposição dos seus respectivos bens ${ }^{66}$, responsabilizando-se individualmente pelas dívidas contraídas.

A estipulação do regime dá-se em razão de convenção em pacto antenupcial ${ }^{67}$ ou em virtude da lei, hipótese em que constitui regime obrigatório na forma do quanto, entre nós, estabelece o parágrafo único do artigo 258, C. Civil.

62 O Art. 263 do C. Civil arrola uma a uma as hipóteses em que exclui-se a comunhão.

${ }^{63}$ Neste sentido, vale trazer à colação ementa de julgado do Tribunal de Justiça do Rio Grande do Sul ao apreciar a Apelação Cível n. 70000530956, 7. Câmara Cível, Rel. Sérgio Fernando Vasconcellos Chaves, j. em 03.05.2000, onde se lê:

"Divórcio direto. Comunhão universal. Partilha. Bens adquiridos após a separação de fato não se comunicam. Aquisição de bens posteriormente à separação de fato não implica em comunicabilidade, mormente quando decorrentes de herança, ainda que o casamento seja pelo regime da comunhão universal. É orientação jurisprudencial pacífica hoje que a ruptura efetiva da vida em comum põe termo também ao regime de bens do casamento. Recurso desprovido. (Grifamos)

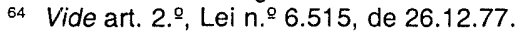

65 Ob. cit., p. 193.

66 Atente-se para o disposto no art. 276, C. Civil o qual não dispensa a outorga uxória para alienação dos bens imóveis.

${ }^{67}$ Neste sentido, vale transcrever ementa de acórdão do Tribunal de Justiça do Rio Grande do Sul, correspondente à Apelação Cível n. 70000908095, 7. Câmara Cível, Rel. Luiz Felipe Brasil Santos, j. em 31.05.2000 onde se lê:"Divórcio. Regime de bens. Pacto antenupcial de separação de bens. O regime de bens eleito pelo casal quando da celebração das núpcias, é irrevogável, forte no art. 230, CC. Só integram o patrimônio a ser dividido aqueles bens adquiridos por ambos os cônjuges, por força do condomínio existente, e não do regime de bens. Assistência judiciária. Acolhido o pedido de assistência judiciária em sede de apelação, eis que não apreciado no curso da demanda, mesmo tendo sido postulado. Deram parcial provimento." (Grifamos) 
O regime da separação ${ }^{68}$ divide-se ${ }^{69}$ em: a) Separação pura - prescreve a incomunicabilidade de todos os bens presentes e futuros, corresponde à separação absoluta $^{70}$ que somente é aceita quando expressamente convencionada em pacto antenupcial. b) Separação limitada - é aquela que não alcança os bens adquiridos na constância do casamento. Assemelha-se, sob esta ótica, ao regime da comunhão parcial de bens (art. 259, C. Civil). A separação pura constitui exceção ${ }^{71}$, presumindo-se na ausência de disposição expressa que a separação é limitada, insere-se nesta modalidade a separação obrigatória de bens $\mathrm{s}^{72}$ e 73 .

Pode-se destacar os seguintes efeitos decorrentes do regime de separação: a) cada cônjuge permanece com a propriedade plena dos bens que possui ao casar $\mathrm{e}$ daqueles adquiridos na constância do casamento; b) os bens são administrados por seus respectivos titulares; c) cada cônjuge pode dispor livremente dos bens móveis, necessitando da outorga do outro para alienação dos bens imóveis; d) cada cônjuge responde pelas dívidas assumidas; e) ambos os cônjuges devem contribuir para as despesas do casal. ${ }^{74}$

${ }_{68}$ Sobre o assunto manifestou-se o Tribunal de Justiça do Rio Grande do Sul ao apreciar a Apelação Civel n. ${ }^{\circ}$ 598448843, 7. ․ㅡ Câmara Cível, Rel. a Maria Berenice Dias, j. em 22.11.2000, assim ementada: "Casamento. Regime de bens. Sub-rogação. Evidenciado que, quando do casamento pelo regime da separação de bens, o patrimônio pertencia exclusivamente à mulher, é de se reconhecer a subrogação nas transaçōes imobiliárias ocorridas durante o período da vida em comum, tendo havido, inclusive, a redução do acervo. Apelo improvido."

69 A classificação é de Orlando GOMES. Ob. cit., p. 193-5.

70 A propósito, já decidiu o Tribunal de Justiça do Rio Grande do Sul ao apreciar os Embargos Infringentes n.ำ 70000829952, 4. Grupo de Câmaras Cíveis, Rel. Rui Portanova, j. em 10.11.2000, em cuja ementa se lê:"Regime de bens. Separação total. Comunicabilidade. Reserva nas sociedades por açōes. As reservas de correção monetária do capital, são bens que não se comunicam quando se trata de casamento com separação total de bens. Acolheram." (Grifamos)

71 Assim, João Andrades CARVALHO. Ob. cit., p. 115.

72 Neste sentido, o enunciado da Súmula 377 do STF estabelece que: "No regime da separação legal de bens, comunicam-se os adquiridos na constância do casamento."

${ }^{73}$ A este respeito pronunciou-se o Tribunal de Justiça do Rio Grande do Sul ao apreciar o Agravo de Instrumento n. .070002510709 , 7. ${ }^{\text {a }}$ Câmara Cível, Rel. Luiz Felipe Brasil Santos, j. em 20.06.2001, assim ementado:"Sucessões. Regime de separação obrigatória de bens. Comunicação dos aqüestos. Súmula 377 , do STF. Incidente, na espécie, a Súmula 377, do STF, que impõe, mesmo neste regime de bens, a comunicaçāo dos aqüestos, sendo de destacar que este colegiado tem admitido que tal comunicação se dá independentemente de prova de contribuição. Havendo ou não testamento (e aqui não está em questão o testamento frise-se que nem sequer foi acostado a este recurso), importa definir a existência ou não de direito de meação sobre o bem. Isto pela singela razão de que meação não se confunde com direito hereditário. $E$, eventualmente reconhecida ela, por evidente o quinhão da agravante será bastante superior (pois resultante da soma da meação mais o direito sucessório) do que ocorreria na hipótese contrária. Sub-rogação. A eventual prova da aquisição de determinado bem por sub-rogação é apta a elidir a comunicação, uma vez que a justificativa da regra sumular repousa na evitação do enriquecimento sem origem lícita, o que fica afastado com a comprovação de que tal se deu com o produto da venda de bem pré-existente. A sub-rogação, entretanto, há que resultar extreme de dúvida, por constituir exceção, caso contrário a interpretação deve ser no sentido da regra de que ocorre a comunicação. Hipótese em que não ficou demonstrada a sub-rogação, por não haver equivalência de valores. Deram provimento." (Grifamos)

74 A classificação foi recolhida em Orlando GOMES. Ob. cit., p. 194. 
d) Regime dotal

O regime dotal ${ }^{75}$ caracteriza-se, essencialmente, pela constituição do dote que corresponde aos bens que a mulher, ou alguém em seu favor, repassa ao marido quando da realização do casamento com a finalidade de auxiliar nas despesas do casal, mediante seus frutos e rendimentos, enquanto durar a sociedade conjugal.

Aponta-se como traço distintivo entre o regime dotal e o da separação de bens ${ }^{76}$ o fato de, no primeiro, a destinação dos bens da mulher ter fim específico.

A opção pelo regime deve ser expressa em pacto antenupcial, consubstanciado em escritura pública, no qual restarão especificados os bens que compóem o dote (art. 278, C. Civil).

A constituição do dote ${ }^{\eta \eta}$ - que pode compreender um ou mais bens, desde que determinados - pode ser feita pela própria nubente, por seus ascendentes ou, ainda, por terceiros. ${ }^{78 \mathrm{e}} 79$

Os bens que compõem o dote estão cobertos pelo manto da inalienabilidade e incomunicabilidade ${ }^{80}$. Distingue-se, então, no patrimônio da mulher, os bens dotais e os extradotais ou parafernais na dicção do Código (art. 310).

Aponta-se como peculiaridade desse regime o fato de os bens dotais, quando estipulado no pacto antenupcial, poderem conviver com outros bens submetidos a regime diverso. Assim, também, quando a constituição do dote for efetuada por terceiros, após a celebração do casamento permanece intacto o regime previamente estabelecido.

No regime dotal, admite-se a estipulação de cláusulas especiais dentre as quais destaca-se a de reversão (art. 283, C. Civil), segundo a qual uma vez dissolvida a sociedade conjugal, os bens que constituem o dote retornarão ao patrimônio do dotador. Entretanto, se assim não for estabelecido é obrigatória a restituição do dote à mulher

\footnotetext{
75 A sua raríssima utilizaçāo permite que façamos uma' abordagem sintética do tema que vem tratado em inúmeros dispositivos legais (arts. 278 a 310 ).

76 Considerando que ambos, como visto ao início, incluem-se dentro dos regimes ditos não comunitários.

77 Observado o disposto no art. 261, C. Civil.

78 Vide arts. 279 e 280, C. Civil.

79 Neste sentido, Caio Mário da Silva PEREIRA observa que: "Quando constituido pela nubente, pode abranger a totalidade ou parte de seus bens. Se oferecido por seus pais, é adiantamento de legítima; e pelos avós sujeita-se à colação quando a dotada Ihes suceder. Constituído por terceiros, subordina-se às regras das doaçōes com encargos, não respondendo o dotador pela evicção senão no caso de proceder ele de má-fé, ou ter havido estipulação expressa." Ob. cit., p. 130-1.

${ }^{80}$ Orlando GOMES. Ob. cit., p. 196.
} 
ou à seus herdeiros por ocasião dissolução da sociedade conjugal, nos termos do que preceitua o art. 300, C. Civil.

O marido assume, em relação aos bens dotais, a condição de administrador. Assegura-se o direito à percepção dos frutos, bem como, a possibilidade de valer-se de ações judiciais, sempre que necessário.

São estes, em linhas gerais, os regimes matrimoniais de bens previstos no Código Civil. Resta-nos, agora, examinar as novidades trazidas pelo Projeto do novo Código Civil.

Civil

B) O tratamento dispensado ao regime de bens no Projeto do novo Código

No que tange ao Direito de Família, o Projeto trilhou a orientação dada por Clóvis do CoUTO E SILVA ${ }^{81}$ e, partindo do mestre, não surpreende a visão inovadora que contempla. Exemplo disso, é a estrutura do Livro IV que trata do Direito de Família a qual difere substancialmente da atual.

O Código de 1916, como a maioria dos códigos, examina o Direito de Família de modo estanque ${ }^{82}$, mediante a análise dos diversos institutos que o compóem. $O$ Projeto, a sua vez ousa, ao estruturar o Direito de Família levando em conta a distinção entre Direito de Família Pessoal e Patrimonial, atento a especificidade das relaçóes jurídicas presentes em cada espécie. ${ }^{83}$

Clóvis do Couto E SiLva, justifica sua opção ao aludir que: "A distinção entre Direito Pessoal e Patrimonial de Família provém do fato de o ordenamento jurídico não poder deixar de valorizar as relações dos partícipes da família, levando em conta seus atributos de pessoalidade e patrimonialidade já existentes na dimensão social." ${ }^{44}$

Prossegue afirmando: "Ao transpor para o ordenamento esses dados objetivos, distinguiu-se o Direito Pessoal do Direito Patrimonial, os dois conjuntos de relações básicas que formam o Direito de Família e que, apesar de sua diversidade, ou, talvez, por isso mesmo, se implicam dialeticamente." ${ }^{85}$

81 Miguel REALE. O Projeto do Novo Código Civil. São Paulo: Saraiva. 1999. p. 2.

82 Neste sentido, Eduardo Silva da SILVA. "Projeto do Código Civil - A importância das Cláusulas Gerais na Regulação do Direito Pessoal e Patrimonial de Família". Revista da Faculdade de Direito UFRGS, v. 15, p. 60.

${ }^{83}$ Assim, Clóvis do COUTO E SILVA. "Direito Patrimonial de Família no Projeto de Código Civil Brasileiro e no Direito Português". Revista dos Tribunais, v. 520, p. 14.

84 Idem.

${ }^{85}$ Ibidem. 
Aponta-se, ainda, como traço distintivo do Projeto, no que se refere ao Direito Pessoal de Família, o emprego da técnica legislativa das cláusulas gerais ${ }^{86}$, dentre as quais destaca-se a da comunhão plena de vida ${ }^{87}$ que encabeça o art. 1.509.

Com efeito, interessa para o presente estudo os aspectos relativos ao Direito Patrimonial de Família ${ }^{88}$ onde se insere a disciplina do regime de bens entre os cônjuges. Neste passo, permitimo-nos apontar as inovaçóes e alterações constantes do Projeto de Código Civil.

O Projeto, mantém a irrevogabilidade do regime de bens (art. 1.667, § 1.9 $)^{89}$. Entretanto, admite alteração parcial do regime mediante autorização judicial a pedido de ambos os cônjuges, ressalvado o interesse de terceiros (art. 1.667, § 2.9) ${ }^{90}$.

Conserva, o Projeto, disposição que permite aos nubentes, antes da celebração do casamento, estipular quanto aos seus bens o que lhes for conveniente. Mantendo, assim, o pacto antenupcial. ${ }^{91}$

Permanece o regime da comunhão parcial de bens como regime legal, na ausência de estipulação em contrário ${ }^{92}$. O Projeto, conserva, também, os regimes da comunhão universal e da separação de bens, exclui, contudo, o regime dotal para inserir no ordenamento o regime de participação final nos aqüestos.

Mantém, ainda, a exigência da separação obrigatória nos casos elencados no art. 1.669: (I) das pessoas que contraírem casamento sem observância às causas suspensivas da sua celebração; (II) dos maiores de sessenta anos (aqui uma novidade pois o Projeto equipara, quanto a idade, homem e mulher, diversamente, do que previa o inc. II, parágrafo único, art. 258 do Código atual); e (III) dos que dependem de autorização judicial para casar.

\footnotetext{
${ }^{86}$ Veja-se Judith MARTINS-COSTA. "As cláusulas gerais como fatores de mobilidade do sistema juridico". Revista de Informaçāo Legislativa, v. 112, p. 13-32.

87 Confira-se Eduardo Silva da SILVA. Ob. cit., p. 63-6.

${ }^{88}$ Como assevera Clóvis do COUTO E SILVA: "O conceito fundamental no Direito de Família Patrimonial é o de administração." Significa dizer que: "O 'pater familias' não tem sua atividade orientada em seu favor, pois, quando administra bens de seu filho, sua ação, obrigatoriamente, deve realizar-se em favor do administrado (...)". "Direito Patrimonial de Família no Projeto de Código Civil Brasileiro e no Direito Português". Revista dos Tribunais, v. 520, p. 16.

${ }^{89}$ Anoto que a numeração dos artigos arrolados é a constante da obra assinada por Juarez de OLIVEIRA e Antônio Cláudio da Costa MACHADO. Novo Código Civil. São Paulo: Oliveira Mendes, 1998.

90 Neste sentido, esclarece Clóvis do COUTO E SILVA: “(...) sendo marido e mulher capazes, como o são desde o advento da Lei n. ${ }^{4} 4121$, de 1962, razão alguma parece existir para a munutenção do princípio da imodificabilidade dos regimes matrimoniais." "Direito Patrimonial de Família no Projeto de Código Civil Brasileiro e no Direito Português". Revista dos Tribunais, v. 520, p. 16-7.

91 Veja-se o art. 1.667, bem como, os arts. 1.681 a 1.685 do PCC.

92 Art. 1.668, PCC.
} 
Suprimiu-se a obrigatoriedade da adoção deste regime para o órfão e menor cujos pais decaíram do pátrio poder.

O caput do artigo em referência ${ }^{93}$ introduz alteração significativa ao prever a incomunicabilidade dos bens adquiridos na constância do casamento, quando o regime bens for o da separação obrigatória. Este dispositivo modifica a interpretação que até então a jurisprudência vinha emprestando ao tema, na esteira do enunciado da Súmula n. 377 do Supremo Tribunal Federal.

É de se observar, ainda, que o Projeto excluiu a chamada separação limitada ou relativa ao náo repetir a regra constante do art. 259 do $\mathrm{C}$. Civil, sendo mais coerente com a opção eleita pelos nubentes.

O Projeto consagra no art. 1.670 o princípio da igualdade entre os cônjuges estabelecido pela Constituição Federal de 1988 (§ 5. ${ }^{\circ}$, art. 226), superando as inadequaçóes da atual legislação infraconstitucional.

Quanto à administração dos bens, perduram algumas restrições ${ }^{94}$ relativas ao poder de disposição sobre os bens imóveis; ao exercício do direito de ação quanto a tais bens; relativamente à prestação de fiança ou aval; $\mathrm{e}$, ainda, quanto à doaçáo graciosa de bens comuns ou que venham integrar a futura meação.

O art. 1.676 mantém a possibilidade de intervenção judicial para suprimento da outorga uxória. ${ }^{95}$

Examinemos, agora, às disposições relativas aos regimes em espécie.

a) Regime da Comunhão Parcial

As disposições relacionadas ao regime da comunhão parcial de bens foram mantidas com algumas adequações, ajustando-se seus artigos à concepção de igualdade entre os cônjuges.

Neste sentido, o art. 1.686 estabelece que: "No regime da comunhão parcial, comunicam-se os bens que sobrevierem ao casal, nà constância do matrimônio, com as exceções dos artigos seguintes." Tem-se, portanto, uma disposição mais precisa que privilegia a regra da comunicabilidade, diversamente daquela prevista no atual Código onde a comunicabilidade derivava da exclusão.

93 O dispositivo possui a seguinte redação: "Art. 1.669 - É obrigatório o regime da separação de bens no casamento, sem a comunhão dos aqüestos:" (...)

${ }^{94} \mathrm{Na}$ forma do art. 1.675 exige-se o consentimento do outro cônjuge para prática de determinados atos.

95 Veja-se, também, o disposto nos arts. 1.677 e 1.678 , PCC. 
Na seqüência, o art. 1.687 arrola os bens que são excluídos da comunhão repetindo, praticamente, as disposiçóes do atuais artigos 269 e 270 do C. Civil, com a supressão dos incisos III e IV do art. 269, acrescentando que, também, ficam excluídos da comunhão os bens de uso pessoal, os livros e instrumentos de profissã ${ }^{96}$; os proventos do trabalho pessoal de cada cônjuge; as pensōes, meios-soldos, montepios e outras rendas similares ${ }^{97}$. Note-se, ainda, que são excluídas as obrigações decorrentes de ato ilícito, desde que não tenham revertido em proveito do casal.

De sua vez, o art. 1.688 descreve os bens que ingressam na comunhão preservando o disposto no art. 271 do C. Civil, excluído o inc. VI. Aqui, uma alteração importante, pois não mais se incluem na comunhão os frutos civis do trabalho, ou indústria de cada cônjuge, ou de ambos, disposição que foi incorporada ao artigo antecedente.

Os artigos 1.689 e 1.690 reproduzem a regra constante nos artigos 272 e 273 do C. Civil.

O artigo 1.691, incorpora os ajustes a que nos referimos anteriormente, ao prescrever: "A administração do patrimônio comum compete a qualquer dos cônjuges."

O $\S 1 .{ }^{\circ}$ do art. 1.691, regula questão relativa às dívidas repetindo o que preceitua o art. 274, C. Civil ao considerar como critério para estabelecer a comunhão em relação aos bens particulares do outro cônjuge o proveito auferido.

Constitui novidade o $§ 2$. o do art. 1.691 que determina a anuência de ambos os cônjuges para a prática de atos, a título gratuíto, que constituam cessáo de uso ou gozo dos bens comuns. Também o $§ 3 .^{\circ}$ deste mesmo dispositivo apresenta-se como inovação ao prever que em caso de malversação dos bens comuns poderá o juiz atribuir a administração destes bens a apenas um dos cônjuges.

Por sua vez, o art. 1.692 trata das obrigações assumidas pelos cônjuges com a finalidade de atender aos encargos da família, à despesas de administração dos bens e aquelas decorrentes de imposição legal, pelas quais respondem os bens do patrimônio comum.

O art. 1.693 disciplina a situação dos bens particulares que permanecem com o cônjuge proprietário, admitida convenção em contrário em pacto antenupcial.

\footnotetext{
${ }_{96}$ Esta disposição encontra similaridade com a atual redação do art. 263, IX, CC, que trata da comunhão universal e foi, praticamente, arrastada de lá para incorporar-se ao regime regra.

97 Também, aqui, vale a observação feita na nota supra com a seguinte ressalva, substituiu-se o atual inc. I do art. 263, CC por regra equivalente.
} 
Encerrando o capítulo, o art. 1.694 estabelece a incomunicabilidade das dívidas relativas aos bens particulares de cada cônjuge, contraída em favor destes, com os bens comuns.

b) Regime da Comunhão Universal

No que diz com o regime da comunhão universal de bens penso que o destaque vai para o número reduzido de dispositivos que tratam da matéria (cinco) o que explicase pelo fato de não mais representar o regime-regra ${ }^{98}$, examinemos mais de perto sua estrutura.

O art. 1.695 que inaugura o Capítulo IV que disciplina o regime da comunhão universal repete, praticamente, disposição constante no art. 262 do C. Civil.

O dispositivo seguinte ${ }^{99}$ que trata dos bens excluídos da comunhão e tem como referência o art. 263, C. Civil apresenta algumas peculiaridades. A primeira delas é o fato de nada mencionar sobre as obrigações provenientes de atos ilícitos, pelo que entendemos deva-se aplicar o estabelecido para o título no regime da comunhão parcial, regime-regra segundo o Projeto.

No mais, repetem-se as disposições constantes dos atuais incisos II, III, VII e VIII do art. 263 do C. Civil. Excluem-se, todavia, àquelas previstas nos incisos IV, V, VI, IX, X, XI, XII e XIII do mencionado dispositivo, acrescentando que também ficam excluídos da comunhão os bens mencionados nos incisos V a VII do art. 1.687.

A seu turno, o art. 1.697 reedita o estatuído no art. 265 do C. Civil, quanto aos frutos. Assim, também sucede com o art. 1.699 que repisa regra posta no art. 268, C. Civil.

Por fim, o art. 1.698 faz remissão ao disposto no regime da comunhão parcial quanto à administração dos bens.

c) Regime de Participação Final nos Aqüestos

A grande novidade quanto ao regime de bens no casamento fica por conta da inserção, no nosso ordenamento jurídico, do regime de participação final nos aqüestos que passamos a analisar.

\footnotetext{
${ }_{98}$ A expressão é utilizada por Clóvis do COUTO E SILVA. "Direito Patrimonial de Família no Projeto de Código Civil Brasileiro e no Direito Português". Revista dos Tribunais, v. 520, p. 24-5, e "Direito Patrimonial de Família". Revista da Faculdade de Direito da UFRGS, v. 1, p. 43-4.

99 Referimo-nos ao art. 1.696, PCC.
} 
Clóvis do Couto e Silva, justifica sua opção ao expressar que o regime de participação final nos aqüestos é o que melhor espelha o princípio da igualdade dos cônjuges, daí tê-lo eleito como regime-regra o que, contudo, não foi acatado pelos demais membros da comissão. ${ }^{100}$

Em outro trabalho ${ }^{101}$ o mesmo autor define o regime dizendo: "O sistema constitui uma feliz combinação do regime da separação de bens com o da separação limitada. Caracteriza-se, assim, pelo fato de que durante o casamento cada cônjuge administra e dispóe dos bens que lhe são próprios anteriores e posteriores ao casamento; antes da dissolução do casamento, por divórcio ou sucessão, tudo se passa como se o regime fôsse de simples separação de bens. No momento da dissolução, verifica-se, por confronto dos bens adquiridos durante o casamento, se o montante obtido por cada cônjuge superou o do outro, atribuindo-se em dinheiro, por metade, essa diferença patrimonial a quem adquiriu menos."

Este conceito vem expresso nos artigos 1.700 e 1.702 do Projeto. $O$ art. 1.701 esclarece que o patrimônio pessoal de cada cônjuge é composto pelos bens que cada qual possuía ao casar, bem como por aqueles adquiridos, a qualquer título, durante o casamento.

O parágrafo único do artigo em referência ${ }^{102}$ disciplina que a administração dos bens pessoais será exercida, modo exclusivo, pelo cônjuge proprietário que poderá aliená-lo, independente do consenso do outro, se forem móveis.

De sua vez, o art. 1.703 estabelece que a apuração do montante dos aqüestos levará em conta, também, o valor das doações feitas por um dos cônjuges, sem a respectiva autorização do outro. Nesta hipótese, prevê a possibilidade de reivindicação do bem, por parte do cônjuge prejudicado, faculdade que se estende aos herdeiros. Admitindo-se, ainda, que o bem seja declarado no monte partilhável pelo seu valor equivalente à época da dissolução.

Na seqüência, o art. 1.704 esclarece que os bens alienados em detrimento da meação ingressam no monte, ausente reivindicação por parte do cônjuge prejudicado ou de seus herdeiros.

\footnotetext{
${ }^{100}$ COUTO E SILVA, Clóvis. "Direito Patrimonial de Familia no Projeto de Código Civil Brasileiro e no Direito Português". Revista dos Tribunais, v. 520, p. 24-5.

101 COUTO E SILVA, Clóvis. "Direito Patrimonial de Família". Revista da Faculdade de Direito da UFRGS, v. 1, p. 45-6.

102 Art. 1.701, PCC.
} 
$\mathrm{O}$ art. 1.705 determina que as dívidas contraídas, após o casamento, exclusivamente, por um dos cônjuges obrigam somente a este, exceto prova de que reverteram parcial ou totalmente em proveito do outro cônjuge.

O artigo seguinte ${ }^{103}$, também, disciplina questão relativa às dívidas. $O$ dispositivo cuida da possibilidade de que um dos cônjuges venha saldar dívida do outro com patrimônio próprio e estabelece que o valor do pagamento, atualizado, deverá ser imputado à meação do outro cônjuge na data da dissolução.

O art. 1.707 determina que cada cônjuge terá igual quota no condomínio ou no crédito estabelecido sobre os bens adquiridos com o trabalho conjunto.

De sua vez, o art. 1.708 exara a presunção de que os bens móveis, em face de terceiros, presumem-se integrantes do patrimônio do cônjuge devedor, ressalvada hipótese de que seja bem de uso pessoal do outro.

Já o art. 1.709 assenta regra de que a propriedade dos bens imóveis será aferida de acordo com a titularidade do registro. ${ }^{104}$

Na seqüência o art. 1.710 determina a irrenunciabilidade, impenhorabilidade e impossibilidade de cessão do direito à meação, durante a vigência do regime matrimonial de bens.

O art. 1.711 prescreve que havendo dissolução do regime de bens por separação judicial, o montante dos aqüestos será apurado na data em que esta for requerida.

Dispõe o art. 1.712 acerca da impossibilidade ou inconveniência da divisão dos bens em face de sua natureza, neste caso, calcular-se-á o valor de alguns ou de todos, fins de que a reposição ao cônjuge não proprietário seja feita em dinheiro. Acaso, não se viabilize de tal modo a reposição os bens serão avaliados e, ouvido o juiz, alienados quantos bastem para tanto. ${ }^{105}$

O art. 1.713 remete aos dispositivos antecedentes a apuração da meação, em caso de dissolução da sociedade conjugal por morte de um dos cônjuges.

Encerrando o capítulo estabelece o art. 1.714 que as dívidas contraídas por um dos cônjuges, ultrapassada sua meação, não obrigam ao outro cônjuge nem aos herdeiros.

\footnotetext{
${ }^{103}$ Art. 1.706, PCC.

${ }^{104}$ Atente-se para o que dispōe o parágrafo único desse artigo.

105 É o que recomenda o parágrafo único do art. 1,712.
} 
Por se constituir em novidade, o regime de participação final nos aqüestos tem sido alvo de comentários e críticas, ora favoráveis ora desfavoráveis, compartilhamos a opinião daqueles que vêem esta inovação de forma positiva.

Neste passo, considero que a inserção deste regime no Projeto possibilita a concretização do princípio da igualdade entre os cônjuges sob o seu aspecto patrimonial, especialmente, pelo fato de que em não se tratando de regime-regra deverá ser expressamente pactuado pelos nubentes.

d) Regime da Separação de Bens

Trata-se da separação convencional, estabelecida pelos nubentes em pacto antenupcial. A exemplo do que ocorre no atual sistema, no Projeto este regime vem sintetizado em dois únicos dispositivos legais.

O art. 1.715 praticamente repete regra contida no atual art. 276, C. Civil, porém o faz de forma mais ampla na medida em que estabelece que os cônjuges podem alienar, doar ou gravar de ônus real seus bens, móveis ou imóveis, independentemente, do consentimento do outro.

Arrematando, o art. 1.716 prescreve a obrigatoriedade de ambos os cônjuges contribuírem para as despesas do casal na proporção dos rendimentos de seu trabalho e de seus bens, ressalvado ajuste em contrário em pacto antenupcial.

Em apertada síntese, este o tratamento atribuído à disciplina do regime matrimonial de bens pelo Projeto do novo Código Civil. Cumpre, agora, analisarmos os reflexos patrimoniais decorrentes da convivência em união estável. 


\section{UNIÃO ESTÁVEL: REFLEXOS PATRIMONIAIS}

Esta segunda parte do nosso estudo será dedicada a análise da união estável ${ }^{106} \mathrm{e}$ seus reflexos patrimoniais ${ }^{107}$. Para tanto examinaremos a disciplina constante da Lei n.o 8.971/94 (A), bem como, a normatizaçáo imposta pela Lei n. 9.278/96 (B) e, por fim, o tratamento dispensado ao tema no Projeto de Código Civil (C). ${ }^{108}$

\section{A) O regramento da Lei $\mathrm{n} . \stackrel{\circ}{8.971 / 94}$}

Após o advento da Carta Constitucional de 1988, preocupou-se o legislador em regulamentar as hipóteses ali contempladas no que respeita ao reconhecimento da união estável ${ }^{109}$. Nesta esteira, surgiu a Lei n. 0 8.971, de 29.12.1994 que regula o direito dos companheiros relativo aos alimentos e à sucessão, examinemos, pois, as disposiçóes ali contidas.

O caput do art. 1. assim preceitua: "A companheira comprovada de um homem solteiro, separado judicialmente, divorciado ou viúvo, que com ele viva há mais de 5 (cinco) anos, ou dele tenha prole, poderá valer-se do disposto na Lei n. 9 5.478, de 25 de julho de 1968, enquanto não constituir nova união e desde que prove a necessidade."

106 Acerca da evolução do instituto do concubinato, nominado pela Constituiçāo Federal de união estável, veja-se precioso estudo de Álvaro Villaça AZEVEDO. "Uniāo Estável". Revista do Advogado. São Paulo: AASP, 2000, n.ำ 58, p. 14-29. Veja-se, também, o apanhado elaborado por Gustavo TEPEDINO. "As uniōes estáveis entre a Constituição e a recente legislação especial". Ensaios Jurídicos: O Direito em Revista, v. 2, especialmente, p. 485-94, bem como, a análise de Carlos Alberto Menezes DIREITO. "Da União Estável". In O Direito na Década de 1990: novos aspectos. Estudos em homenagern ao Prof. Arnold Wald. Coord. Paulo Dourado de GUSMÃO, p. 126-45, inserto na mesma obra texto de Semy GLANZ sob o título "União Estável", p. 187-211 e, ainda, o artigo de Antônio Carlos Mathias COLTRO. "Novos aspectos relativos à união estável". In Repertório de Jurisprudência e Doutrina sobre Direito de Familia. Aspectos constitucionais, civis e processuais, v. 3, (Coord.), Teresa Arruda ALVIM. São Paulo: Revista dos Tribunais. 1996, p. 19-44.

107 Anoto que, em virtude das críticas e divergênciais surgidas em razāo do advento das Leis $n .^{\circ} \mathrm{S}$ 8.971/94 e 9.278/96 o Ministério da Justiça houve por bem designar uma Comissão de Juristas presidida pelo Ministro Waldemar Zveiter, do Superior Tribunal de Justiça, coordenada e relatada pelo Prof. Arnold Wald sendo integrada, ainda, pelo Ministro Carlos Alberto Direito, também do Superior Tribunal de Justiça, dando origem ao Projeto de Lei $n$. 2.686/96, em tramitação legislativa, conforme dá conta Antônio Carlos Mathias COLTRO. "A União Estável no Direito Projetado - o Código Civil". In Repertório de Jurisprudência e Doutrina sobre Direito de Família. Aspectos constitucionais, civis e processuais, v. 4. (Coord.) Teresa Arruda Alvim WAMBIER e Eduardo Oliveira LEITE . São Paulo: Revista dos Tribunais, 1999. p. 32.

${ }_{108}$ Embora não se desconheça as diferenças terminológicas constantes nestes dois diplomas legislativos, observadas por Luiz Edson FACHIN ("Contribuição crítica à teoria das entidades familiares extramatrimoniais". In Repertório de Jurisprudência e Doutrina sobre Direito de Família. Aspectos constitucionais, civis e processuais, v. 3. (Coord.) Teresa Arruda ALVIM. São Paulo: Revista dos Tribunais p. 96-8) preferimos compreendê-las de modo abrangente, considerando seu objetivo maior que é o de regulamentar situaçōes que nāo se enquadram na disciplina do casamento, mas se afeiçoam à união estável.

109 Sobre o assunto veja-se Antônio Carlos Mathias COLTRO. "A União Estável: um conceito?" In Repertório de Jurisprudência e Doutrina sobre Direito de Familia. Aspectos constitucionais, civis e processuais, v. 3, (Coord.) Teresa Arruda ALVIM. São Paulo: Revista dos Tribunais. 1996, p. 19-44. 
Através desta disposição reconhece-se, no dizer de Álvaro VIllaça AzEvedo, aos companheiros iguais direitos e deveres atribuídos aos cônjuges em relação aos alimentos. ${ }^{110}$

O dispositivo em foco estende aos companheiros à possibilidade de utilizarem do rito especial contemplado na Lei n. ${ }^{\mathrm{o}}$ 5.478/68 sabido, entretanto, que tal opção implica necessariamente na existência de "prova pré-constituída da obrigação alimentar" ${ }^{111}$ o que torna indispensável a demonstração ${ }^{112}$ da união estável. ${ }^{113}$

A comprovação mencionada, remete ao atendimento dos requisitos ali enumerados. ${ }^{14}$ Com efeito, estabelece o aludido dispositivo como requisitos indispensáveis ao reconhecimento do direito à percepção de alimentos para companheira ou companheiro ${ }^{115}$ : (a) inexistência de impedimento para o casamento; e (b) convivência por período superior a 5 anos ou a existência de prole. ${ }^{116}$

O primeiro requisito, afasta a incidência da lei em comento nos relacionamentos surgidos durante a separação de fato, como acentua Luís AlberTo D'AzEvedo AURVAlLE ${ }^{117}$. Todavia, como observa Luiz EDSON FACHIN dita enumeração "não há de ser taxativa, em especial, levando-se em conta certas situações de separação de fato, provada e prolongada."118

\footnotetext{
110 Ob. cit., p. 21.

111 Conforme esclarece Luiz Felipe Brasil SANTOS. "Breves notas sobre a Lei n. ${ }^{\circ} 8.971 / 94$ ". Revista Ajuris, v. 63, p. 316-7.

112 Lia Palazzo RODRIGUES sustenta a desnecessidade de prova da união estável para obtenção dos alimentos: "Revendo minha posição a respeito, penso que a união estável, quanto aos efeitos patrimoniais, produz as mesmas conseqüências do casamento celebrado pela comunhão parcial de bens: aqueles havidos durante a vigência da vida em comum devem ser partilhados por igual independentemente da prova da contribuição dos companheiros para sua aquisição." "Algumas considerações a respeito da Lei 8.971". Revista Ajuris, v. 63, p. 313.

113 Contudo, adverte Luiz Felipe Brasil SANTOS que esta demonstração acaba por afastar a sumariedade da demanda o que de certa forma, inviabilizará a concessão de alimentos provisórios retirando, por assim dizer, o benefício que justificaria a opção por tal rito. Ob. cit., p. 317.

114 Não é outra a opinião de Luiz Edson FACHIN. "Contribuição crítica à teoria das entidades familiares extramatrimoniais". In Repertório de Jurisprudência e Doutrina sobre Direito de Família. Aspectos constitucionais, civis e processuais, v. 3. (Coord.) Teresa Arruda ALVIM. São Paulo: Revista dos Tribunais. 1996, p. 105-6.

115 Contemplado no Parágrafo Único do aludido dispositivo.

116 A estes requisitos Lia Palazzo RODRIGUES agrega o "elemento intencional", ou seja, o "animus de viverem realmente como se fossem marido e mulher, envolvendo-se numa relação séria, com propósito de permanência, assistência mútua e fidelidade reciproca". Ob. cit., p. 309.

${ }_{117}$ "A regulamentação infraconstitucional dos alimentos na união estável". Revista Ajuris, v. 64, p. 247.

118 "Contribuição crítica à teoria das entidades familiares extramatrimoniais". In Repertório de Jurisprudência e Doutrina sobre Direito de Familia. Aspectos constitucionais, civis e processuais, v. 3. (Coord.) Teresa Arruda ALVIM. São Paulo: Revista dos Tribunais. 1996, p. 105.
} 
Quanto ao segundo requisito, saliente-se que a simples existência de prole não é suficiente para caracterizar a união estável e com isto, possibilitar o exercício do direito alimentar. Tal requisito, não pode se afastar do espírito do legislador que buscou imprimir um caráter de "estabilidade ao relacionamento" 119 para daí extrair os aludidos efeitos jurídicos.

No que diz com o lapso temporal de 5 anos exigido pelo legislador, inexistente prole. Há manifestações doutrinárias que defendem que este prazo deve ser tomado com certo temperamento, observando a situação concreta posta em causa. ${ }^{120}$

Compreendemos a preocupação, mas ao nosso ver tais considerações hão de ser feitas pela jurisprudência ao apreciar o caso concreto o que não afasta a presença do requisito temporal apontado que em si visa resguardar o direito aos alimentos a quem, efetivamente, mantinha um convívio estável ${ }^{121}$.

Acrescem-se a esses pressupostos a ausência de constituição de nova união e a comprovação da necessidade dos alimentos, repetindo a exigência prevista no art. 399 do C. Civil da qual não se pode afastar a regra do art. 400 do mesmo diploma legal que prevê que os alimentos serão prestados de acordo com as possibilidades do alimentante.

Outro aspecto que emerge do dispositivo em foco diz respeito a perquirição ou não da culpa, para fins de obtenção dos alimentos. Há diferentes opiniōes sobre o tema, alguns sustentam a impossibilidade de "o convivente culpado da rescisão do contrato concubinário, seja escrito ou não, possa pleitear alimentos do inocente" ${ }^{122}$.

\footnotetext{
119 Assim, Luiz Edson FACHIN. "Contribuição crítica à teoria das entidades familiares extramatrimoniais". In Repertório de Jurisprudência e Doutrina sobre Direito de Familia. Aspectos constitucionais, civis e processuais, v. 3. (Coord.) Teresa Arruda ALVIM. Sāo Paulo: Revista dos Tribunais. 1996, p. 106.

${ }^{120}$ Neste sentido, Lia Palazzo RODRIGUES afirma: "(...) caracterizada a vida more uxorio, mesmo antes de transcorrido o prazo legal de cinco anos, e mesmo sem a existência de prole, impõe-se a partilha dos bens adquiridos durante a constância do companheirismo, independentemente de qualquer outra comprovação que não a existência da uniāo estável". Ob. cit., p. 313. Na mesma esteira, Antônio Carlos Mathias COLTRO sustenta que: "(...) não se pode considerar o aspecto tempo da união como absolutamente necessário à verificação sobre seus efeitos, cuidando-se de aspecto a ser examinado em cada caso e consoante as peculiaridades que apresentar. "A União Estável: um conceito?" In Repertório de Jurisprudência e Doutrina sobre Direito de Familia. Aspectos constitucionais, civis e processuais, v. 3 , (Coord.) Teresa Arruda ALVIM. São Paulo: Revista dos Tribunais. 1996, p. 35. Em sentido contrário, Álvaro Villaça AZEVEDO defende que: "(...) entre os conviventes, esse direito-dever alimentar surge, tão-somente, após o decurso do prazo de cinco anos ou o nascimento de filho." Ob. cit., p. 21.

121 Confira-se, a propósito, manifestação do Tribunal de Justiça do Rio Grande do Sul ao apreciar a Apelação Civel n. 70001137777, 7." Câmara Cível, Rel. Sérgio Fernando de Vasconcellos Chaves, j. em 28.06.2000, assim ementada:"União estável. Incorrência de coabitação. Prova. Identidade física do juiz. Nulidade. Inocorrência. 1. A nulidade do decisum, por violação ao disposto no artigo 132 do CPC, reclama demonstração cabal do prejuízo para a parte que argúi. 2. O relacionamento íntimo sem coabitação e sem a affectio maritalis, não configura união estável nem produz as seqüelas de ordem patrimonial albergada pelas Leis $8.971 / 94$ e $9.278 / 96$. Rejeitaram a prefacial. Negaram provimento ao recurso." ${ }^{122}$ Álvaro Villaça AZEVEDO, Ob. cit., p. 21.
} 
Outros $^{123}$, contudo, afiançam que o dispositivo em análise não cogita da presença ou não de culpa dispensando qualquer exame sobre a culpabilidade para os efeitos ali explicitados. Esta, parece-nos a posição mais acertada.

Na seqüência, o art. 2.ำ regula o direito à sucessão nos termos previstos nos seus três incisos. Os incisos I e II estabelecem, em favor do companheiro sobrevivo, o direito ao usufruto dos bens do falecido o qual poderá ser de quarta parte ou metade, tendo em vista a existência ou não de filhos.

Estes dois incisos ${ }^{124}$ repetem a regra contida no $§ 1 .^{\mathrm{o}}$ do art. 1.611, C. Civil o qual faz a mesma previsão em relação ao cônjuge sobrevivente, desde que o regime de bens não seja o da comunhão universal.

Álvaro VILlaça AzEvedo tece veemente crítica a este dispositivo: "Entendo não conveniente essa reafirmação, para os conviventes, do aludido direito a usufruto, pois, na prática, ele estorva o direito dos herdeiros. Melhor seria tornar o convivente sobrevivo herdeiro, adquirindo sua parte na herança concorrendo com os aludidos filhos (...)."125

O inciso III do artigo 2. estabelece que: "na falta de descendentes e de ascendentes, $o(a)$ companheiro(a) sobrevivente terá direito à totalidade da herança." Esta disposição traz importantes conseqüências ao reconhecer que o companheiro sobrevivo passa à condição de herdeiro. ${ }^{126}$ Neste sentido, já decidiu o Tribunal de

${ }^{123}$ Assim, Sérgio Gischkow PEREIRA. "A União Estável e os Alimentos”. Revista Ajuris, v. 49, p. 47; Luiz Edson FACHIN, "Contribuição crítica à teoria das entidades familiares extramatrimoniais". In Repertório de Jurisprudência e Doutrina sobre Direito de Familia. Aspectos constitucionais, civis e processuais, v. 3. (Coord.) Teresa Arruda ALVIM. São Paulo: Revista dos Tribunais. 1996, p. 106-7; Luís Alberto d'Azevedo AURVALLE. Ob. cit., p. 257; Lia Palazzo RODRIGUES, Ob. cit., p. 313.

124 Lia Palazzo RODRIGUES sustenta a inconstitucionalidade dos incisos I e II do artigo 2. argumentando que "o legislador colocou os companheiros em situação mais vantajosa do que a dos cônjuges (...). O cônjuge sobrevivente só fará jus ao usufruto vidual se o regime de bens do casamento for comunhão parcial (o que nāo é pacífico nem na doutrina nem na jurisprudência) ou a separação total. O companheiro sobrevivente sempre terá direito ao usufruto que a nova leí prevê." Acreditamos, contudo, que a diversidade de tratamento não importa em inconstitucionalidade, posto que não se pode admitir em relação a união estável não se pode cogitar de comunhão universal de bens. Regime que beneficiava o cônjuge sobrevivente o que afastava a incidência da regra em tela.

125 Ob. cit., p. 21.

${ }^{126}$ Neste sentido, já decidiu o Tribunal de Justiça do Rio Grande do Sul ao apreciar a Apelação Cível n. ${ }^{\circ}$ 70001903293, 7. . Câmara Cível, Rel. Luiz Felipe Brasil Santos, j. em 21.03.2001, assim ementada:

“Apelação civel. União estável. A prova carreada bem demonstra a convivência more uxorio havida entre a apelada e o falecido que se iniciou em julho de 1995 até o passamento deste, nāo tendo perdurado mais no tempo dado ao infortúnio ocorrido. Direito sucessório. Não tendo deixado o falecido descendentes ou ascendentes, a companheira herda, conforme dispõe a Lei n. ${ }^{\circ} 8.971 / 94$ (art. $2 .{ }^{\circ}$, inciso III). Desproveram o apelo."Nesta esteira, o julgamento dos Embargos Infringentes n. ${ }^{\circ} 70002891208$, 4. ${ }^{\circ}$ Gupo de Câmaras Cíveis, Rel. José Ataídes Siqueira Trindade, j. em 14.09.2001, em cuja ementa se lê::"Embargos infringentes. União estável. Reconhecimento. Direito da companheira sobrevivente à sucessão universal. Reconhecida a existência da uniāo estável, a unanimidade, a companheira sobrevivente tem direito à totalidade da herança deixada pelo extinto, uma vez inexistentes herdeiros necessários. Aplicação do art. 2.․․ III, da Lei no 8.971/94 que dispõe sobre o direito sucessório na união estável, o qual não foi revogado pela Lei $n$. . 9.278/96. Precedentes doutrinário e jurisprudencial. Embargos infringentes desacolhidos, por maioria." 
Justiça do Rio Grande do Sul ao apreciar a Apelação Cível n.o 70001903293, 7. Câmara Cível, Rel. Luiz Felipe Brasil Santos, j. em 21.03.2001, assim ementada:

Com efeito, observado o regramento acima posto tem-se que ao companheiro sobrevivente alcança-se maior direito que ao cônjuge ${ }^{127}$ em igual situação, na medida que este último pode ser excluído da herança, por vontade do cônjuge falecido o que não se dá em relação ao primeiro. ${ }^{128}$

Por fim, a regra contida no inciso III $^{129}$ contempla o direito à meação sobre os bens adquiridos com esforço comum. $O$ dispositivo requer a prova da colaboração do companheiro sobrevivo sem, contudo, mensurar o "grau dessa cooperação", como observa Luiz EDSON FACHIN ${ }^{130}$ o que em certos casos pode dificultar a concretização deste direito, sabendo-se que a colaboração pode ser de cunho moral ou material.

Contudo, a meação deve se dar tão-somente sobre os bens adquiridos à título oneroso na constância da união. ${ }^{131}$

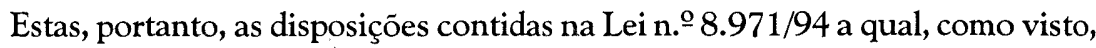
não se preocupou em conceituar a união estável, limitando-se a elencar alguns requisitos que se justificam, apenas, para fins sucessórios e alimentares posto que, quanto ao mais, esta lei acabou sendo substituída pela Lei n. 9 9.278/96 como se verá adiante.

\section{B) A disciplina da união estável na Lei n. 9 9.278/96}

Os contornos da união estável estão previstos na Lei n. ${ }^{\circ}$ 9.278/96 que regula o $\S 3$. do art. 226 da CF/88. Também, aqui, não se preocupou o legislador em conceituar o instituto, embora não deixe de fazê-lo ao especificar os pressupostos para sua configuração. ${ }^{132}$

\footnotetext{
127 Assim, Álvaro Villaça AZEVEDO. Ob. cit., p. 22.

${ }_{128}$ Neste sentido, as observações de Luiz Edson FACHIN, "Contribuição crítica à teoria das entidades familiares extramatrimoniais". In Repertório de Jurisprudência e Doutrina sobre Direito de Família. Aspectos constitucionais, civis e processuais, v. 3. (Coord.) Teresa Arruda ALVIM. Sāo Paulo: Revista dos Tribunais. 1996, p. 108.

129 O dispositivo tem a seguinte redação: "Quando os bens deixados pelo(a) autor(a) da herança resultarem de atividade em que haja colaboração do(a) companheiro(a), terá o sobrevivente direito à metade dos bens"

130 "Contribuição crítica à teoria das entidades familiares extramatrimoniais". In Repertório de Jurisprudência e Doutrina sobre Direito de Família. Aspectos constitucionais, civis e processuais, v. 3. (Coord.) Teresa Arruda ALVIM. São Paulo: Revista dos Tribunais. 1996, p. 109.

131 Assim, Álvaro Villaça AZEVEDO, Ob. cit., p. 22. Eduardo Oliveira LEITE, antes mesmo da vigência

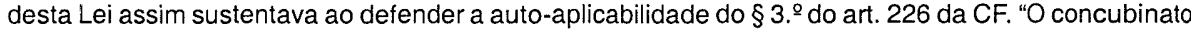
frente à nova Constituição: hesitações e incertezas". In Repertório de Jurisprudência e Doutrina sobre Direito de Familia. Aspectos constitucionais, civis e processuais, v. 1. (Coord.) Teresa Arruda ALVIM. Sāo Paulo: Revista dos Tribunais. 1993, p. 105.
}

132 Neste sentido, Álvaro Villaça AZEVEDO. Ob. cit., p. 23. 
Em seu o art. 1. ${ }^{\mathrm{i}}$ indica os requisitos conformadores da união estáve ${ }^{133}$. Assim, reportando-se ao texto constitucional anuncia: "É reconhecida como entidade familiar a convivência duradoura, pública e contínua, de um homem e uma mulher, estabelecida com o objetivo de constituição de família." Vale dizer, com a finalidade de comunhão de vida e de interesses.

Segundo acentua Edgar Moura BitTencourt: "A comunhão de vida e de interesses entre os conviventes estará presente quando demonstradas fiquem a recíproca afeição, a assistência mútua e a conjugação de esforços em benefício de ambos."134

Assim, para configuração da união estável é necessário um convívio duradouro ${ }^{135}$. Com efeito, preferiu o legislador não fixar um lapso temporal "fechado" a exemplo do que fizera a Lei n. $.8 .971 / 94^{136}$, cabendo ao poder judiciário verificar a ocorrência deste pressuposto no caso concreto.

133 Vale repisar o entendimento do Tribunal de Justiça do Rio Grande do Sul, a respeito, o que se traduz nas ementas que se seguem: "União estável. Requisitos. Partilha de bens. Acervo havido antes da Constituição de 1988. Meação. Contribuição indireta. É razoável a declaração de união estável, quando fartamente preenchidos os pressupostos que comprovam a vida comum, notória, com decadência. A partilha observa o regime da comunhão parcial, mesmo sobre o acervo havido antes da Carta Federal de 1988, consolidado o entendimento de que ali vigora a contribuição indireta da mulher para aquisição do cabedal. Apelações, provida em parte e desprovida." (Apelação Cível n. ${ }^{7}$ 70001936277, 7. ․ Câmara Cível, Rel. José Carlos Teixeira Giorgis, j. em 04.04.2001) "Uniāo estável. Pressupostos. Partilha. Honorários. Cumpridos os pressupostos da relação entretida, são partilhados os bens havidos durante a convivência, respeitada a sub-rogação de recursos oriundos de acervos pessoais do companheiro, existentes antes da vinculação afetiva. O decaimento de parcela da pretensão exige estabelecimento de verba honorária para a parte sucumbente, proporcional a redução. Apelação provida, em parte, para fixar honorários." (Apelação Cível n. ${ }^{0} 70002529428,7 . \underline{a}$ Câmara Cível, Rel. José Carlos Teixeira Giorgis, j. em 06.06.2001) "Ação de reconhecimento e dissolução de união estável. Lapso temporal. Partilha. O marco inicial da união estável é aquele onde as partes efetivamente passaram a conviver como se casados fossem. No relacionamento estável partilham-se somente os bens adquiridos durante a convivência. Eventuais empréstimos monetários a outra parte antes da convivência, não integram a partilha, se não restituídos devem ser buscados em sede própria. Apelação e recurso adesivo desprovidos." (Apelação Cível n.ำ 70003520616, 8. ․ Câmara Cível, Rel. José Ataídes Siqueira Trindade, j. em 20.12.2001)

134 Concubinato. 1980 , p. 25. Apud, Paulo Martins de CARVALHO FILHO. "Lei $n . \cong 9.278$ (de 10 de maio de 1996) a Uniāo Estável". Revista dos Tribunais, v. 734, p. 13-39.

135 Ilustrativa, a propósito, é a manifestação do Tribunal de Justiça do Rio Grande do Sul ao apreciar a Apelação Cível n. 70000900787, 7. a Câmara Cível, Rel. Sérgio Feranando de Vasconcellos Chaves, j. em 17.05.2000, assim ementada: "União estável. Duração. Dissolução. Sentença ultra petita. 1. Comprovada a existência da vida em comum por quase quatro anos, com fidelidade e publicidade, configurada está a união estável, inexistindo exigência legal do lapso temporal de cinco anos. Diante disso, imperiosa a partilha igualitária dos bens adquiridos durante a convivência marital, sendo certa a colaboração de cada convivente, o que decorre de presunção jure et de jure. 2. A sentença deve adequar-se à pretensão deduzida quando é extra petita. O valor a ser dividido é o da efetiva venda do bem e nāo o da avaliação fiscal, mormente quando inexiste qualquer discussão a respeito. Recurso provido em parte."

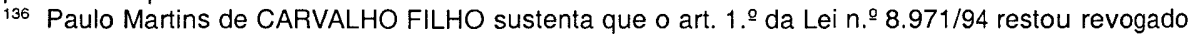
em face do que prescrevem os arts. $1 .^{\circ}$ e $7 .^{\circ}$ da Lei $n . \stackrel{9}{9.278 / 96}$. Ob. cit., p. 17 . Todavia, nos parece que uma disposição não exclui a outra. 
A este requisito, liga-se a necessidade de continuidade no convívio que sugere uma certa estabilidade à união. De outra parte, ao estabelecer o artigo a exigência de que a convivência seja pública quis afastar da proteção legal as unióes "clandestinas". ${ }^{137}$

Na seqüência, o art. 2.o estabelece como direitos e deveres dos conviventes: I respeito e consideração mútuos; II - assistência moral e material recíproca ${ }^{138}$; III guarda, sustento e educação dos filhos comuns.

Embora o legislador não tenha incluído, expressamente, a fidelidade recíproca nesse rol é evidente que tal dever insere-se na exigência de respeito e consideração mútuos. ${ }^{139 \text { e } 140}$

De outra parte, bem andou o legislador ao afastar a necessidade do convívio more $u x$ xorio $^{141}$ para o reconhecimento da união estável como faz o inc. II do art. 231, C. Civil, em relação ao casamento. ${ }^{142}$

Destaca, ÁlVARo VILLAÇA AzEVEDO, a importância do dever de assistência moral na atualidade, onde as pessoas pouco se comunicam no lar. ${ }^{143} \mathrm{~A}$ assistência material, de sua vez, reflete-se no aspecto patrimonial em que um dos conviventes tem o dever de auxiliar o outro quando necessário prestando-lhe, por exemplo, alimentos.

Com efeito, os direitos e deveres previstos nos incisos I e II são recíprocos entre os conviventes, ao passo que a hipótese elencada no inciso III refere-se aos deveres destes em relação aos filhos comuns.

137 Assim, Paulo Martins de CARVALHO FILHO. Ob. cit., p. 15.

${ }_{138}$ A propósito, vale registrar manifestação do Tribunal de Justiça do Rio Grande do Sul ao apreciar a Apelação Cível n. ${ }^{\circ} 70000796292$, 7." Câmara Cível, Rel. Sérgio Fernando de Vasconcellos Chaves, j. em 21.06.2000, assim ementada: "Alimentos. Companheira. Necessidade de suplementação da aposentadoria. Embora a autora não tenha sido dependente do réu por exercer atividade remunerada, criou-se entre o casal um vínculo afetivo sólido, determinante do compromisso moral e jurídico de mútua assistência ex vi das Leis $n .^{\circ}$ s 8.971/94 e 9.278/96. Ficando claro que a autora enfrenta privações diante da sua minguada aposentadoria previdenciária, sendo cardíaca e com limitaçōes laborativas, o que decorre até da idade de 65 anos, e tendo o varão razoável situação econômica, impōe-se a fixação de alimentos para garantir a ex-companheira uma vida digna, nesta quadra da sua vida. Recurso provido em parte."

139 Idem.

140 Marilene Silveira GUIMARĀES, aponta o respeito e consideração mútuos como subsidiários ao dever de fidelidade recíproca constante do Código Civil. "A união estável e a Lei n. 9.278 , de 13-0596". Revista Ajuris, v. 68, p. 176; e Luiz Edson FACHIN. "Contribuição crítica à teoria das entidades familiares extramatrimoniais". In Repertório de Jurisprudência e Doutrina sobre Direito de Família. Aspectos constitucionais, civis e processuais, v. 3. (Coord.) Teresa Arruda ALVIM. São Paulo: Revista dos Tribunais. 1996, p. 104.

${ }^{141}$ Como já assentado pelo Supremo Tribunal Federal ao editar a Súmula n. ${ }^{\circ} 382$ que tem o seguinte teor: "A vida em comum sob o mesmo teto, more uxorio, não é indispensável à caracterização do concubinato."

142 Assim, Paulo Martins de CARVALHO FILHO. Ob. cit., p. 16.

143 Ob. cit., p. 23. 
O art. 3.que dispunha sobre o contrato escrito, do qual os conviventes poderiam fazer uso para regrar seus interesses, foi vetado.

Por estar relacionado ao artigo anterior, dispondo a respeito do registro do

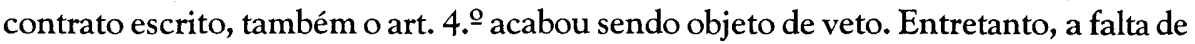
previsão específica não inibe a utilização desse instrumento que serve, inclusive, como prova da união estável. ${ }^{144}$

Restando a questão patrimonial estabelecida no art. 5. o e seus parágrafos ${ }^{145}$ e 146 que estabelece verdadeiro condomínio entre os conviventes ${ }^{147}$, quanto aos bens adquiridos na constância da união estável a título oneroso a exemplo do que ocorre no regime da comunhão parcial de bens. ${ }^{148}$

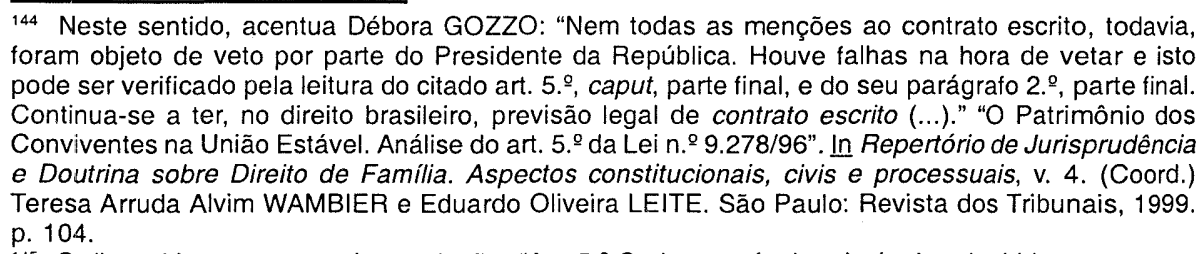

${ }^{145}$ O dispositivo tem a seguinte redação: "Art. 5.ํ Os bens móveis e imóveis adquiridos por um ou ambos os conviventes, na constância da uniāo estável e a título oneroso, são considerados fruto do trabalho e da colaboração comum, passando a pertencer a ambos, em condomínio e em partes iguais, salvo estipulação em contrário em contrato escrito." $§ 1 .{ }^{\circ}$ Cessa a presunção do caput deste artigo se a aquisição patrimonial ocorrer com o produto de bens adquiridos anteriormente ao início da uniāo. "§ 2. A administração do patrimônio comum dos conviventes compete a ambos, , salvo estipulação em contrário em contrato escrito."

146 Paulo Martins de CARVALHO FILHO sustenta que este dispositivo revogou o art. 3.9 da Lei n.․ 8.971/94 que fazia reviver o enunciado da Súmula 380 do STF, restando superada esta interpretação em face do que dispôs o art. 5. da Lei n. 9.278/96. Ob. cit., p. 19-27. Na mesma esteira é o pensamento de Álvaro Villaça AZEVEDO. Ob. cit., p. 28 e Débora GOZZO. Ob. cit., p. 99. Em sentido contrário, Luiz Edson FACHIN entende que os dispositivos se complementam inexistindo incompatibilidade entre um e outro. "Contribuição crítica à teoria das entidades familiares extramatrimoniais". In Repertório de Jurisprudência e Doutrina sobre Direito de Família. Aspectos constitucionais, civis e processuais, v. 3. (Coord.) Teresa Arruda ALVIM. São Paulo: Revista dos Tribunais. 1996, p. 109-10.

147 Presunção esta dita relativa, em vista do próprio conteúdo da norma - conforme observa Débora GOZZO - que possibilita aos conviventes estabelecerem de modo diverso em contrato escrito. $O b$. cit., p. 103.

148 Assim, Paulo Martins de CARVALHO FILHO. Ob. cit., p. 19. 
O dispositivo presume ${ }^{149}$ o esforço comum dos conviventes para constituição do patrimônio, possibilitando a partilha em partes iguais ${ }^{150}$. Exceção a esta regra, vem prevista no $\S 1 .^{\circ}$ que exclui da partilha os bens dados em sub-rogação real. ${ }^{151}$ Vale registrar o entendimento do Tribunal de Justiça do Rio Grande do Sul, sobre o tema, o que se traduz nas ementas que se seguem:

"Embargos infringentes. União estável. Reconhecimento. Reconhecida pelo próprio embargado e corroborada pelas testemunhas a existência da união estável com início após a separação de fato da esposa, seu reconhecimento não pode ser afastado na ação intentada pela companheira. Partilha de bens adquiridos em sub-rogação. Descabimento. Por aplicação

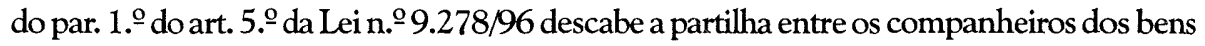
adquiridos em sub-rogação aqueles pré-existentes à união estável. Embargos infringentes parcialmente acolhidos." (Embargos Infringentes n. 70001131002 , 4.ํㅡㅁo de Câmaras Cíveis, Rel. José Ataídes Siqueira Trindade, j. em 20.10.2000)

149 Trata-se de presunção juris tantum admitindo, portanto, prova em contrário. Neste sentido, Àlvaro Villaça AZEVEDO, Ob. cit., p. 25; e Luiz Edson FACHIN, "Contribuição crítica à teoria das entidades familiares extramatrimoniais". In Repertório de Jurisprudência e Doutrina sobre Direito de Família. Aspectos constitucionais, civis e processuais, v. 3. (Coord.) Teresa Arruda ALVIM. São Paulo: Revista dos Tribunais. 1996, p. 110.

${ }^{150}$ Neste sentido, já decidiu o Tribunal de Justiça do Rio Grande do Sul ao apreciar a Apelação Cível n.․․ 70002418390, 7. a Câmara Cível, Rel. Luiz Felipe Brasil Santos, j. em 02.052001, em cuja ementa se lê: "Apelação cível. União estável. Partilha de bens. O imóvel, objeto do litígio, foi adquirido na constância da união estável através de financiamento, para pagamento em 240 meses. Neste compasso, tendo sido adquirido a título oneroso, deve ser partilhado em iguais proporções entre as partes, incluindo-se na divisão o saldo devedor remanescente (prestações vincendas junto ao DEHMAB). Aplicação do art. 5. da Lei n. ${ }^{\circ}$ 9.278/96. Outrossim, a sentença não determinou a venda do bem, apenas acenou, na fundamentação, que, futuramente, deverá ser este o caminho a ser percorrido, ante a circunstância de que, formado o condomínio, sua extinção só poderá dar-se por esta forma. Desproveram o apelo."

${ }^{151}$ Vale registrar o entendimento do Tribunal de Justiça do Rio Grande do Sul, sobre o tema, o que se traduz nas ementas que se seguem: "Embargos infringentes. União estável. Reconhecimento. Reconhecida pelo próprio embargado e corroborada pelas testemunhas a existência da união estável com início após a separação de fato da esposa, seu reconhecimento não pode ser afastado na ação intentada pela companheira. Partilha de bens adquiridos em sub-rogação. Descabimento. Por aplicação do par. 1. do art. 5. ${ }^{9}$ da Lei $n .^{\circ} 9.278 / 96$ descabe a partilha entre os companheiros dos bens adquiridos em sub-rogação aqueles pré-existentes à união estável. Embargos infringentes parcialmente acolhidos." (Embargos Infringentes n. $.70001131002,4 .^{\circ}$ Grupo de Câmaras Cíveis, Rel. José Ataídes Siqueira Trindade, j. em 20.10.2000) "Dissolução da união estável. Partilha de bens. Comprovada a união estável durante o período de 1991 a 2000, durante o qual ocorreu formação de patrimônio, e tendo em conta a ausência de provas de terem os bens sido adquiridos em sub-rogação de outros exclusivos do apelante, a partilha deve ser igualitária, face a presunção absoluta de que foram adquiridos com esforço comum. Desproveram. Unânime." (Apelação Cível n.ำ70002979110, 7. a Câmara Civel, Rel. Luiz Felipe Brasil Santos, j. em 19.12.2001) "Uniāo estável. Partilha de bens. Caso em que se reconhece a união estável e o direito do companheiro ao partihamento do imóvel adquirido na constância do companheirismo. Negaram provimento." (Apelação Cível n. 70003929049, 8. ${ }^{a}$ Câmara Cível, Rel. Rui Portanova, j. em 27.03.2002) "União estável. Partilha de bens. A presunção de que os bens adquiridos na constância da união estável são considerados fruto do trabalho comum não permite inquirir sobre a real participação de cada um dos conviventes na formação do acervo patrimonial. Apelo desprovido." (Apelação Cível n.․70003399425, 7.․ㅡ Câmara Cível, Rel.. Maria Berenice Dias, j. em 24.04.2002) "Uniāo estável. Comunicação dos bens. Irrelevante o fato de a uniāo estável haver iniciado antes da vigência da Lei $n .99 .278 / 96$, uma vez que a presunção de mútua colaboração, a gerar o estado condominial e conseqüente partição paritária, já estava consagrada pela jurisprudência mesmo antes da entrada em vigor da Constituição Federal. Apelo desprovido." (Apelação Cível n.o 70004040309, 7. amara Cível, Rel. a Maria Berenice Dias, j. em 08.05.2002) 
A partilha, em face da dissolução da união estável, independe de indagação sobre culpa, conforme acentua PAULO MARTINS de CARVALHo FilHo. ${ }^{152}$

$\mathrm{O} \S 2 . \mathrm{o}$ do artigo em comento, observando a igualdade entre os conviventes, estabelece que a administração do patrimônio comum há de ser exercida por ambos os conviventes, ressalvando a hipótese de estipulação contrária em contrato escrito.

O art. 6. ${ }^{\circ}$ que tratava da dissolução da união estável, também, foi objeto de veto.

Na seqüência, o caput do artigo 7. dispōe acerca da prestação de assistência material - que se dará sob a forma de alimentos -, em caso de dissolução da união estável, por rescisão. ${ }^{153}$

Em face desta previsão, sustenta ÁlvaRo VILlAÇA AzEvEDO a revogação parcial do art. 1. da Lei n.o 8.971/94 aduzindo que somente serão devidos alimentos, após a dissolução da união estável se houver culpa, cabendo ao convivente culpado prestar os alimentos àquele que não deu causa a dissolução. ${ }^{154 \mathrm{e}} 155$

Em sentido contrário ${ }^{156}$, Gustavo TePedino bem define a controvérsia ao explicitar: “(...) embora o art. 7. da Lei n. 9 9.278/96 faça infeliz referência à rescisão, modalidade extintiva da relação negocial prevista na dicção vetada do art. 6. , não se poderia limitar a sua concessão à demonstração de culpa no rompimento da união estável, mesmo a prescindir da Lei n.o 8.971/94. A ratio da disciplina dos alimentos, inspirada, como anteriormente já se procurou demonstrar, por valores constitucionais relativos à dignidade da pessoa humana e à realização da personalidade dos cônjuges e dos filhos, volta-se para os laços de solidariedade familiar, não se justificando a restrição interpretativa." 157 Parece-nos ser esta a interpretação mais adequada.

O parágrafo único do mesmo artigo, disciplina o direito real de habitação ${ }^{158}$ na hipótese de dissolução da união estável por morte de um dos conviventes, em relação 152 Ob. cit., p. 19.

153 Como a lei fala em rescisão, Álvaro Villaça AZEVEDO defende que o dever de assistência material deva ser prestado pelo convivente culpado ao inocente, acaso este demonstre necessitar dos alimentos. 154 Ob. cit., p. 28.

155 No mesmo sentido, Paulo Martins de CARVALHO FILHO que, contudo, enfatiza que acaso a dissolução da união estável se dê em face de acordo ou denúncia de um dos conviventes, permanece o direito a alimentos desde que presente o binômio: necessidade-possibilidade. Ob. cit., p. 16.

156 Seguido por Luiz Edson FACHIN. "Contribuição crítica à teoria das entidades familiares extramatrimoniais". In Repertório de Jurisprudência e Doutrina sobre Direito de Familia. Aspectos constitucionais, civis e processuais, v. 3. (Coord.) Teresa Arruda ALVIM. São Paulo: Revista dos Tribunais. 1996, p. 106-7; Marilene Silveira GUIMARÃES. Ob. cit., p. 180-181.

${ }_{157}$ "As uniōes estáveis entre a Constituição e a recente legislação especial". Ensaios Jurídicos: $O$ Direito em Revista, v. 2, p. 503.

${ }_{158}$ Veja-se o disposto nos arts. 746 a 748 do Código Civil. 
ao imóvel que servia de residência familiar ${ }^{159}$. Na dicção legal o direito real de habitação é vitalício. Cessa, todavia, acaso o convivente sobrevivo constitua nova união ou casamento.

Divide-se a doutrina quanto aos efeitos deste dispositivo legal. De um lado, LUIZ EDSON FACHIN sustenta que o parágrafo único do artigo 7. revogou os incisos I e II do art. 2. da Lei n. 9 8.971/94, permanecendo hígido, entretanto, o inciso III deste artigo. ${ }^{160}$ De outro, Álvaro Villaça Azevedo ${ }^{161}$, seguido por Paulo Martins DE CaRvalho FilHO ${ }^{162}$ entendem que convivem harmonicamente o art. 2.o da Lei n.o 8.971/94 com o parágrafo único do artigo 7. da Lei n.o 9.278/96.

Compartilhamos da primeira opiniáo, pois nos parece que ao estabelecer o direito real de habitação afastou o legislador, embora de modo não expresso, a possibilidade prevista pela lei anterior quanto ao usufruto.

De sua vez, o art. 8.ำ prescreve que: "Os conviventes poderão, de comum acordo e a qualquer tempo, requerer a conversão da união estável em casamento, por requerimento ao Oficial do Registro Civil da Circunscrição de seu domicílio."

Embora a lei não estabeleça a forma em que deverá ser efetuada dita conversão certo é que deverá ser precedida de processo de habilitação, tal qual ocorre em relação ao casamento. ${ }^{163}$

O dispositivo em foco, está em perfeita sintonia com o texto do $§ 3 .^{\circ}$ do art. 226 da Constituição Federal, ao possibilitar a conversão da união estável em casamento, conforme ali preceituado.

159 Neste sentido, vale reproduzir manifestaçāo do Tribunal de Justiça do Rio Grande do Sul, consubstanciado na ementa que se segue:

"União estável. Constituição de 1988. Colaboração presumida. Direito de habitação e usufruto. Sucumbência. 1. A união havida constituiu uma família, sendo irrelevante se iniciou antes da Constituiçāo, importando é que findou sob a égide dessa nova Carta de princípios. A uniāo more uxorio existente antes da Constituição ganhou rótulo de união estável, mas não sofreu qualquer alteraçāo na sua natureza e essência. A nova Carta trouxe ao campo do direito o fato social relevante que reclamava o afastamento dos preconceitos, bem como o reconhecimento formal e a proteção do Estado. 2. Desnecessidade de prova da contribuição para o patrimonial, pois esta é presumida. 3. A Lei n. ${ }^{9}$ 9.278/96 não revogou a Lei n. ${ }^{\circ} 8.271 / 94$, coexistindo o direito real de habitação como 0 usufruto vidual, que é mais benéfico aos conviventes. 4 . Tendo a ação marcante conteúdo declaratório, não tem aplicação a regra do art. 20 , parágrafo $3 .{ }^{\circ}$, do CPC, devendo a fixação decorrer da apreciação eqüitativa do julgador segundo as diretrizes referidas no dispositivo invocado. Recurso provido em parte." (Apelação Cível n. 70000859587, 7.ㄹ Câmara Cível, Rel. Sérgio Fernando de Vasconcellos Chaves, j. em 12.04.2000)

160 "Contribuição crítica à teoria das entidades familiares extramatrimoniais". In Repertório de Jurisprudência e Doutrina sobre Direito de Familia. Aspectos constitucionais, civis e processuais, v.

3. (Coord.) Teresa Arruda ALVIM. São Paulo: Revista dos Tribunais. 1996, p. 108-9.

161 Ob. cit., p. 28.

162 Ob. cit., p. 34.

163 Assim, Álvaro Villaça AZEVEDO, Ob. cit., p. 27; e Gustavo TEPEDINO. "As uniōes estáveis entre a Constituição e a recente legislação especial". Ensaios Jurídicos: O Direito em Revista, v. 2, p. 506. 
Por fim, o art. 9. ${ }^{\circ}$ determina a competência das Varas de Família para apreciarem as questões relativas à união estável assegurado, nos termos da lei, o segredo de justiça. Todavia, é evidente a inconstitucionalidade deste dispositivo ao disciplinar matéria de competência estadual (art. 125, CF) ${ }^{164}$ Caberá, então, aos Estados em atenção a mens legis encaminhar a solução ali apontada.

Examinada, a disciplina da união estável em face da Lei n. 9 9.278/96 resta, ainda, analisarmos a matéria à luz do que dispõe a legislação projetada. Civil

C) O tratamento dispensado à União Estável no Projeto do novo Código

A disciplina da união estável foi absorvida pelo Projeto de Código Civil em razão da ER n.o 462-R, feita pelo Senado Federal, figurando logo após o art. 1.751 . $^{165}$

Neste sentido, menciona ANTÔNIO CARlos Mathias Coltro,as esclarecedoras palavras do Senador JoSAPHAT MARINHO, justificando a inclusão: "A emenda resulta, essencialmente, do disposto no art. 226, § 3.o, da Constituição de 1988 . Nela 'reconhecida a união estável entre o homem e a mulher, como entidade familiar', cumpre situá-la na lei civil básica. Tanto mais se impóe caracterizá-la porque prevista 'para efeito de proteção do Estado' e 'devendo a lei facilitar sua conversão em casamento."."166

O primeiro artigo que trata da matéria assim preceitua: "É reconhecida como entidade familiar a união estável entre o homem e a mulher, vivendo os companheiros ${ }^{167}$ como se casados fossem por mais de cinco anos consecutivos."

Da simples leitura do dispositivo, percebe-se que o legislador retomou o requisito temporal, afastado pela Lei n. 9 9.278/96, ao estabelecer o prazo de 5 anos para configuração da união estável, com a possibilidade de redução para 3 anos se houver filho comum $\S 1$. o reeditando, em parte, o que previa a Lei $\mathrm{n} . \stackrel{\mathrm{o}}{8.971 / 94}$.

\footnotetext{
164 Neste sentido, Gustavo TEPEDINO. Ob. cit., p. 507; e Paulo Martins de CARVALHO FILHO. Ob. cit., p. 38.

165 Não há numeração dos artigos, em face da introduçāo apontada.

166 "A União Estável no Direito Projetado - O Código Civil". In Repertório de Jurisprudência e Doutrina sobre Direito de Familia. Aspectos constitucionais, civis e processuais, v. 4. (Coord.) Teresa Arruda Alvim WAMBIER e Eduardo Oliveira LEITE. São Paulo: Revista dos Tribunais, 1999. p. 32.

${ }_{167}$ Interessante notar que o Projeto utiliza a nomenclatura da Lei n. ${ }^{\circ} 8.971 / 94$, denominada por Luiz Edson FACHIN de "Estatuto do Companheirato" ao tratar os conviventes sempre como companheiros. "Contribuição crítica à teoria das entidades familiares extramatrimoniais". In Repertório de Jurisprudência e Doutrina sobre Direito de Família. Aspectos constitucionais, civis e processuais, v. 3. (Coord.) Teresa Arruda ALVIM. São Paulo: Revista dos Tribunais. 1996, p. 97.
} 
Ressurge, portanto, a polêmica ${ }^{168}$ acerca da conveniência ou não de que o reconhecimento da união estável sujeite-se a este requisito o qual não consta no texto constitucional (§3.. , art. 226)..$^{169}$

Assim, preferível seria a manutenção da redação emprestada pelo art. $10^{\circ}$ da Lei n. $9.278 / 96$ a qual permitia ao julgador à vista dos outros requisitos enquadrar a união como estável, desde que duradoura a convivência.

Na seqüência, o $\S 2.9$ do mesmo dispositivo afasta a possibilidade de reconhecimento da união estável em havendo os impedimentos que seriam aplicáveis ao casamento ${ }^{170}$. O dispositivo explicita, portanto, requisito necessário à própria conversão da união estável em casamento.

Pertinente, todavia, a observação feita por ANTÔNIO CARlos Mathias Coltro, relativamente a viabilidade de admitir-se a união estável envolvendo pessoas separadas de fato. ${ }^{171}$

O artigo seguinte ${ }^{172}$ estabelece os deveres dos conviventes entre si, assim, os deveres de lealdade, respeito e assistência; e destes em relação aos filhos, quais sejam, os deveres de guarda, sustento e educação.

A redação do dispositivo difere daquela contida na Lei n. 9 9.278/96 (art. 2. ${ }^{\circ}$ ), mas é suficiente para evidenciar os elementos que informam o convívio em união estável. Assim, embora a lei não o diga expressamente, dos deveres de lealdade e respeito emerge, também, o de fidelidade.

\footnotetext{
168 Veja-se o teor da Nota 120, supra.

169 Penso que a razão está com Antônio Carlos Mathias COLTRO ao referir: "Fixar-se prazo, segundo nos parece, além de constituir-se em exigência nāo contida na norma constitucional, acabará por ensejar o risco de burla à proteçāo dos conviventes, tanto nos casos em que faltando pouquíssimo tempo para ser completado o lapso temporal ocorrer o término da vida de fato por falta de consenso entre os conviventes, quanto à mantença da mesma, como no de, por exemplo, um deles falecer, o que, de forma alguma, em um e em outro caso, servirá à desconsideração da maneira como até entāo viviam e, que, eventualmente, se preste a indicar ter havido a união estável a que se refere a CF." "A União Estável no Direito Projetado - o Código Civil." In Repertório de Jurisprudência e Doutrina sobre Direito de Família. Aspectos constitucionais, civis e processuais, v. 4. (Coord.) Teresa Arruda Alvim WAMBIER e Eduardo Oliveira LEITE. São Paulo: Revista dos Tribunais, 1999. p. 36. 170 Neste sentido, aliás, já se pronunciou o Tribunal de Justiça do Rio Grande do Sul ao apreciar a

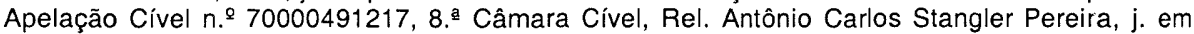
11.10.2001, assim ementada: "Apelação. União estável. Existência de casamento. Não se configura união estável, o relacionamento, entre homem e mulher, quando existe o impedimento para conversão em casamento. O varão casado nunca se separou de sua esposa."

171 "A União Estável no Direito Projetado - o Código Civil." In Repertório de Jurisprudência e Doutrina sobre Direito de Família. Aspectos constitucionais, civis e processuais, v. 4. (Coord.) Teresa Arruda Alvim WAMBIER e Eduardo Oliveira LEITE. São Paulo: Revista dos Tribunais, 1999. p. 40.

172 O dispositivo contém a seguinte redação: "As relações pessoais entre os companheiros obedecerão aos deveres de lealdade, respeito e assistência, e de guarda, sustento e educação dos filhos."
} 
De outro lado, preferiu o legislador utilizar, apenas, o termo assistência, sem especificar que deva ser moral e material o que evidentemente há de se extrair do dispositivo. Manteve, em relação aos filhos, os mesmos direitos assegurados pela Lei n..$^{9}$ 9.278/96.

No que respeita aos aspectos patrimoniais que orientam o convívio na união estável, prescreve o dispositivo seguinte: "Na união estável, salvo convenção válida entre os companheiros, aplica-se às relaçōes patrimoniais, no que couber, o regime da comunháo parcial de bens."

Neste particular, o Projeto estabelece como regra a incidência do regime da comunhão parcial de bens, ressalvando a hipótese de convenção em sentido contrário, pelos companheiros. A norma afina, portanto, com a previsão já existente no art. 5.o,

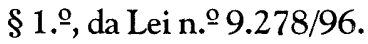

O Projeto, a exemplo do que dispunha o art. 8.ํ da Lei n.․ 9.278/96 e, também, em atenção ao comando constitucional contido no $\S 3 .^{\circ}$ do art. 226 , prevê a possibilidade de conversão da união estável em casamento, mediante requerimento dos companheiros endereçado ao juiz e inscrição no Registro Civil.

Por fim, distingue o Projeto a união estável do concubinato ${ }^{173}$ ao estabelecer no último artigo que trata da matéria que: "As relaçôes não eventuais entre o homem e a mulher, impedidos de casar, constituem concubinato."

Como afirma Antônio Carlos Mathias Coltro: "Distinguiu-se, pois, no enunciado legislativo, a união pura, em que presentes os atributos necessários à produção de efeitos conforme os estabelecidos para fins do art. $226, \S 3 .{ }^{\circ}$, da $\mathrm{CF}$, da união impura, denominada concubinato, e que é tida, assim, como o gênero, 'aplicando-se a todos os casos de união livre entre homem e mulher'; ainda que despojada do caráter pejorativo que antes lhe era aplicado, o estável vem a ser espécie regularmente protegida." ${ }^{174}$

Com isto, pretendeu o legislador evitar eventuais conflitos e confusões na aplicação da lei.

\footnotetext{
173 Retoma, aqui, o caráter pejorativo atribuído, inicialmente, ao termo. Com efeito, antes do advento da Constituição Federal de 1988 já se procurava, em doutrina, estabelecer a distinção entre as várias espécies de concubinato (honesto, adulterino, incestuoso). Atualmente, todavia, a expressão concubinato havia se generalizado como forma de consolidação das uniões livres.

174 "A União Estável no Direito Projetado - o Código Civil." In Repertório de Jurisprudência e Doutrina sobre Direito de Familia. Aspectos constitucionais, civis e processuais, v. 4. (Coord.) WAMBIER, Teresa Arruda Alvim e LEITE, Eduardo Oliveira. São Paulo: Revista dos Tribunais, 1999. p. 41.
} 
Sem a pretensão de exaurimento do tema, mas antes, com o intuito de ter propiciado uma reflexão sobre os aspectos patrimoniais decorrentes da opção por determinado regime de bens no casamento e aqueles surgidos em face do convívio na união estável, alinhamos algumas observações a título conclusivo.

\section{Conclusão}

a) a Constituição Federal de 1988 permitiu uma releitura do Direito de Família ao conceber um novo paradigma de família, fundado em valores autênticos que apontam para afetividade como fonte inspiradora das relações familiares;

b) a disciplina do regime de bens apresenta especial relevo no contexto do Código Civil vigente, regulando os efeitos patrimoniais decorrentes do casamento;

c) o Projeto do novo Código Civil, em boa hora, permite uma renovação do tema ao adequar os regimes de bens à nossa realidade, superando alguns inconvenientes da legislação atual ${ }^{175}$. Contribui, também, para este novo modelo familiar ao estruturar as relações familiares levando em consideração a sua especificidade (pessoal ou patrimonial);

d) ao reconhecer a união estável como entidade familiar que merece proteção do Estado, a Constituição Federal inaugurou um novo capítulo na história do Direito de Família que tem como reflexo a nova concepção do modelo familiar;

e) as Leis n. os $_{\text {s }} 8.971 / 94$ e 9.279/96, inobstante eventuais impropriedades, são a base regulamentadora da união estável e devem servir à concretização da proteção estatal assegurada aos conviventes;

f) afigura-se correta a inserção da disciplina da união estável no Projeto de Código Civil, todavia, parece-nos um retrocesso a exigência de lapso temporal "fechado" para sua configuração, preferível seria fosse mantido, no particular, o texto da Lei n. $9.278 / 96$ (art. 1.9);

g) adequada a previsão do Projeto que determina a aplicação do regime da comunhão parcial de bens às relaçóes patrimoniais entre os conviventes;

h) o Direito de Família passa por uma enorme evolução e o aparato legislativo nem sempre é apto a fornecer, de imediato, as soluçóes para os conflitos jurídicos que se apresentam cabe, portanto, ao operador do direito a tarefa de reduzir esta distância por forma a viabilizar uma adequada interpretaçáo do Direito.

175 Tais como a disciplina do regime dotal. 


\section{Bibliografia:}

ALVIM, Teresa Arruda (Coord.). RepertóriodeJurisprudência e Doutrina sobre Direito de Familia. Aspectos constitucionais, civis e processuais. v. 1 (1993), v. 2 (1995), v. 3 (1996), v. 4 (1999). São Paulo: Ed. Revista dos Tribunais.

"Entidade familiar e casamento formal: aspectos patrimoniais". $\underline{\text { In }}$ Repertório de Jurisprudência e Doutrina sobre Direito de Familia. Aspectos constitucionais, civis e processuais, v. 1. p. 80-93.

AURVALLE, Luís Alberto. "A regulamentaçāo infraconstitucional dos alimentos na união estável”. Revista Ajuris, v. 64, p. 244-58.

AZEVEDO, Álvaro Villaça. "União Estável”. Revista do Advogado. São Paulo, AASP, 2000. N. 58 , p. 14-29.

BITTAR FILHO, Carlos Alberto. "Do regime da separação de bens no direito brasileiro atual”. Revista dos Tribunais, v. 688, p. 7-19.

CAMBI, Eduardo. "Premissas teóricas das unióes extramatrimoniais no contexto da tendência da personificação do Direito de Família”. In Repertório de Jurisprudência e Doutrina sobre Direito de Familia. Aspectos constitucionais, civis e processuais, v. 4. (Coord.) Teresa Arruda Alvim WAMBIER e Eduardo Oliveira LEITE. São Paulo: Revista dos Tribunais, 1999.p. 125-87.

CARVALHO, João Andrades. Regime de bens. Rio de Janeiro: Aide, 1996.

CARVALHO FILHO, Paulo Martins de. "Lei n.o 9.278 (de 10 de maio de 1996) a União Estável”. Revista dos Tribunais, v. 734, p. 13-39.

COLTRO, Antônio Carlos Mathias. "A Constituição Federal e a União Estável entre Homem e Mulher". In Repertório de Jurisprudência e Doutrina sobre Dineito de Familia. Aspectos constitucionais, civis eprocessuais, v. 1. (Coord.) Teresa Arruda Alvim WAMBIER. São Paulo: Revista dos Tribunais. 1993, p. 42-56.

"Novos aspectos relativos à união estável". In Repertório de Jurisprudência e Doutrina sobre Direito de Famillia. Aspectos constitucionais, civis e processuais, v. 2. (Coord.) Teresa Arruda ALVIM. São Paulo: Revista dos Tribunais. 1995, p. 29-43. “A União Estável: um conceito?" In Repertório de Jurisprudência e Doutrina sobre Direito de Familia. Aspectos constitucionais, civis e processuais, v. 3, (Coord.) Teresa Arruda ALVIM. São Paulo: Revista dos Tribunais. 1996, p. 19-44. 
“A União Estável no Direito Projetado - O Código Civil”. In Repertório de Jurisprudência e Doutrina sobre Direito de Familia. Aspectos constitucionais, civis e processuais, v. 4. (Coord.) Teresa Arruda Alvim WAMBIER e Eduardo Oliveira LEITE. São Paulo: Revista dos Tribunais, 1999. p. 27-45.

COUTO e SILVA, Clóvis do. "Direito Patrimonial de Familia no Projeto de Código Civil Brasileiro e no Direito Português". Revista dos Tribunais, v. 520, p. 11-37.

"Direito Patrimonial de Família". Revista da Faculdade de Direito UFRGS, v. 1, p. 39-51.

DIAS, Maria Berenice. "União Homossexual - Aspectos sociais e jurídicos”. Revista Brasileira de Direito de Familia, n. - 4, p. 5-14.

DIREITO, Carlos Alberto Menezes. “Da União Estável.” In ODireito na Década de 1990: novos aspectos. Estudos em homenagem ao Prof. Arnold Wald. (Coord.) Paulo Dourado de GUSMÃO, p. 126-45.

FACHIN, Luiz Edson. "Contribuição crítica à teoria das entidades familiares extramatrimoniais". In Repertório de Jurisprudência e Doutrina sobre Direito de Família. Aspectos constitucionais, civis e processuais, v. 3. (Coord.) Teresa Arruda ALVIM. São Paulo: Revista dos Tribunais. p. 94-113.

“Aspectos Jurídicos da União de Pessoas do Mesmo Sexo". Revista dos Tribunais, v. 732, p. 47-54.

"Projeto do Código Civil". Revista do Centro de Estudos Judiciários$C E J, \overline{\text { n. } 9, \operatorname{Dez} / 99}$, p. 16-20.

$32-4$.

"Direito Civil Contemporâneo". Revista Consulex, n. ํ 18, Jun/98, p.

paradoxos sob o neoliberalismo. (Da função pública ao espaço privado: aspectos da "privatização" da família no projeto do Estado mínimo, a partir da realidade brasileira)". Revista do Direito, Santa Cruz do Sul, n.o 12, p. 13-8, jul-dez/99, p. 13-28.

GOMES, Orlando. Direito de Familia. Rio de Janeiro: Forense. 1996.

GOZZO, Débora. "O Patrimônio dos Conviventes na União Estável. Análise do art. 5. da Lei n. 9 9.278/96". In Repertório de Jurisprudência e Doutrina sobre Direito de Familia. Aspectos constitucionais, civis e processuais, v. 4. Coord. Teresa Arruda Alvim WAMBIER e Eduardo Oliveira LEITE. São Paulo: Revista dos Tribunais, 1999. p. 86 124. 
GLANZ, Semy. “União Estável”. In ODireito na Década de 1990: novos aspectos. Estudos em homenagem ao Prof. Arnold Wald. Coord. Paulo Dourado de GUSMÃO, p. $187-211$.

GUIMARÃES, Marilene Silveira. “A união estável e a Lei n.o 9.278, de 13.05.96 (Comentários em 18.07.96)". Revista Ajuris, v. 68, p. 173-83.

"Reflexões acerca de questōes patrimoniais nas uniōes formalizadas, informais e marginais". In Repertório de Jurisprudência e Doutrina sobre Direito de Familia. Aspectos constitucionais, civis e processuais, v. 2. (Coord.) Teresa Arruda Alvim WAMBIER. São Paulo: Revista dos Tribunais. 1995, p. 197-206.

JAYME, Erik. "Visões para uma Teoria Pós-moderna do Direito Comparado". Revista dos Tribunais, v. 759, p. 23-40.

JUNIOR, Eroulths Cortiano. "O Direito de Família no Projeto do Código Civil”. In Repertório de Jurisprudência e Doutrina sobre Direito de Famulia. Aspectos constitucionais, civis e processuais, v. 4. Coord. Teresa Arruda Alvim WAMBIER e Eduardo Oliveira LEITE. São Paulo: Revista dos Tribunais, 1999. p. 222-43.

LEITE, Eduardo Oliveira. "O concubinato frente à nova Constituição: hesitaçōes e incertezas". In Repertório de Jurisprudência e Doutrina sobre Direito de Familia. Aspectos constitucionais, civis e processuais, v. 1. (Coord.) Teresa Arruda ALVIM. São Paulo: Revista dos Tribunais. 1993, p. 94-107.

"A família monoparental como entidade familiar". In Repertóriode Jurisprudência e Doutrina sobre Direito de Familia. Aspectos constitucionais, civis e processuais, v. 2. (Coord.) Teresa Arruda ALVIM. São Paulo: Revista dos Tribunais. 1995, p. 44-70.

LYOTARD, Jean-François. A condiçãopós-moderna. Trad. Ricardo Corrêa Barbosa.

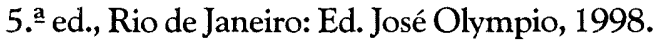

LÔBO, Paulo Luiz da Costa. Igualdade conjugal - direitos e deveres. Revista da ESMAPE. v. 2, n. 6, out/dez-1997, p. 361-80.

A repersonalização das relaçōes de família. In O Direito de Família e a Constituição de 1988. Coord. BITTAR, Carlos Alberto. São Paulo: Saraiva, 1989. p. 53. 81.

MARQUES, Cláudia Lima, CACHAPUZ, Maria Cláudia e VITÓRIA, Ana Paula da Silva. "Igualdade entre filhos no direito brasileiro atual - direito pós-moderno?" Revista dos Tribunais, v. 764, p. 11-32. 
MARTINS-COSTA, Judith. "As cláusulas gerais como fatores de mobilidade do sistema jurídico". Revista de Informação Legislativa, v. 112, p. 13-32.

OLIVEIRA, Euclides de. AMORIN, Sebastião. "Concubinato: novos rumos". Revista de Jurisprudência Brasileira, v. 172. p. 23-32.

OLIVEIRA, Juarez de. e MACHADO, Antônio Cláudio da Costa. Novo Código Civil. São Paulo: Oliveira Mendes, 1998.

PEREIRA, Caio Mário da Silva. Instituiçôes de Direito Civil. Rio de Janeiro: Forense, vol. V, 9. ${ }^{\underline{a}}$ ed., 1994.

PEREIRA, Sérgio Gischkow. "Tendências modernas do direito de familia”. Revista Ajuris, v. 42, p. 52-86.

“A União Estável e os Alimentos". Revista Ajuris, v. 49, p. 36-50.

PONTES DE MIRANDA, F. C. Fontes e evolução do direito civil brasileiro. Rio de Janeiro: Forense. 1981.

REALE. Miguel. OProjeto do Novo Código Civil. São Paulo: Saraiva. 1999.

RODRIGUES, Lia Palazzo. "Algumas considerações a respeito da Lei 8.971". Revista Ajuris, v. 63, p. 305-14.

RODRIGUES, Silvio. Direito Civil. vol. VI, 16. ㄹ ed. atual., São Paulo: Saraiva, 1989.

Revista da Faculdade de Direito da Universidade de São Paulo, v. 88, 1993, p. 239-54.

SANTOS, Luiz Felipe Brasil. "Breves notas sobre a Lei n..$^{8.971 / 94 " . ~ R e v i s t a ~}$ Ajuris, v. 63, p. 315-9.

SILVA, Eduardo Silva. "A importância das cláusulas gerais na regulação do direito pessoal e patrimonial de família". Revista da Faculdade de Direito da UFRGS, v. 15. p. 5573.

TEPEDINO, Gustavo José Mendes. “Qual a Lei para a Nova Família?”In Revista Jurídica, Dez/1999, n. ${ }^{\circ}$ 7, p. 24-5.

"As uniões estáveis entre a Constituição e a recente legislação especial”. Ensaios Jurídicos: ODireito em Revista, v. 2, p. 485-507. 